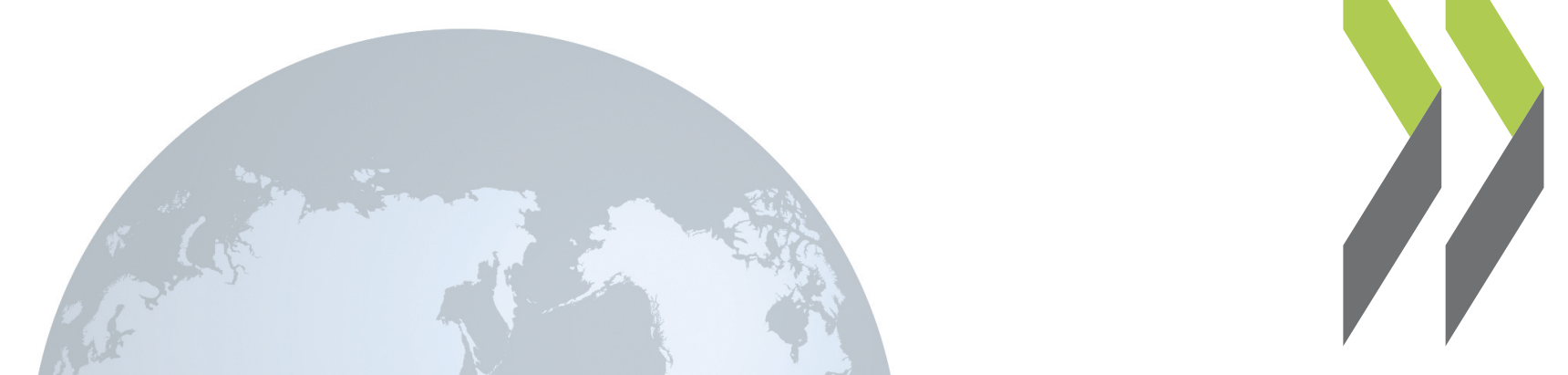

OECD Labour Market and Social Policy Occasional Papers No. 2

\title{
Health and Pension Reform in Japan
}

\section{OECD}


LABOUR MARKET AND SOCIAL POLICY OCCASIONAL PAPERS

No. 2

\section{HEALTH AND PENSION REFORM IN JAPAN}





\section{DIRECTORATE FOR SOCIAL AFFAIRS, MANPOWER AND EDUCATION}

\section{OCCASIONAL PAPERS}

This series is designed to make available to a wider readership selected labour market and social policy studies prepared for use within the OECD. Authorship is usually collective, but principal writers are named. The papers are generally available only in their original language - English or French - - with a summary in the other.

Comment on the series is welcome, and should be sent to the Directorate for Social Affairs, Manpower and Education, 2, rue André-Pascal, 75775 PARIS CEDEX 16, Erance. Additional, limited copies are available on request.

The opinions expressed and arguments employed here are the responsibility of the author $(s)$ and do not necessarily represent those of the OECD. 


\section{LABOUR MARKET AND SOCIAL POLICY OCCASIONAL PAPERS}

(Already available, free of charge)

No. 1 AN ECONOMIC FRAMEWORK FOR THE EVALUATION OF CHILD CARE POLICY (1990)

No. 1 UN CADRE ÉCONOMIQUE POUR L'ÉVALUATION DES POLITIQUES DE GARDE D'ENFANT (1990)

\section{Mailing List for \\ Labour Market and Social Policy Occasional papers}

Please include the following name on the mailing 1 ist:

(write in capitals)

Name

Organisation

Address

Country

This form should be returned to:

Labour Market and Social Policy Occasional Papers

Directorate for Social Affairs, Manpower and Education OECD

2, rue André-Pascal

75775 PARIS CEDEX 16

FRANCE 


\section{A SELECTION OF OECD PUBLICATIONS ALSO AVAILABLE}

"OECD SOCIAL ROLICY STUDIES" SERIES

No. 1 SOCIAL IXPENDITURE 1960-1990: Problems of Growth and Control (1985)

Out of print in English. French text available under the title: No. 1 Dépenses sociales 1960-1990. Problèmes de croissance et de maitrise. $\left(\begin{array}{llll}81 & 85 & 01 & 2\end{array}\right)$ ISBN $92-64-22656-7,100$ pp. $\quad £ 7.50 \quad$ US\$15.00 $\quad$ FF75 DM33

No. 2 MEASURING HWALTH CARE 1960-1983: Expenditure, Costs and Performance (1985) (81 8506 1)ISBN 92-64-12736-4, $162 \mathrm{pp}$.

Out of print. Available on microfiche edition.

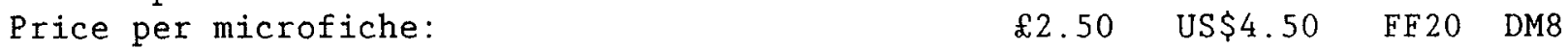

NO. 3 IIVING CONDITIONS IN ORCD COUNTRIES: A Compendium of SOcial Indicators (1986) (81 8504 1) ISBN $92-64-12734-8,166$ pp. £6.50 US\$13.00 FF65 DM29

NO. IINANCING AND DELIVERING HEATTH CARE: A Comparative Analysis Of OECD Countries (1987)

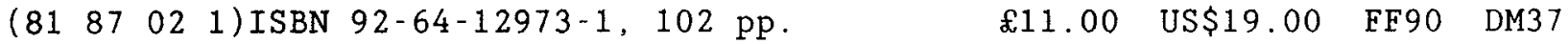

NO. 5 REFORMING PUBLIC PANSIONS (1988)

( $\left.\begin{array}{llll}81 & 88 & 04 & 1\end{array}\right)$ ISBN $92-64-13123-\mathrm{X}, 250 \mathrm{pp} . \quad £ 15.50 \quad$ US\$29.00 FF130 DM56

NO. 6 THE FUTURE OF SOCTAL PROTECTION (1988)

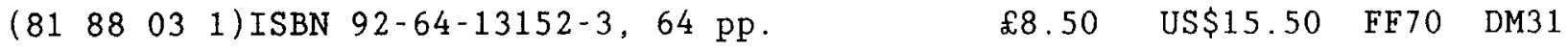

NO. 7 HWATTH CARE SYSTHMS IN TRANSITION: The Search for Efficiency (1990)

(81 89051 ) ISBN $92-64-13310-0,206 \mathrm{pp} . \quad \$ 17.00$ US\$30.00 FF140 DM55

No. 8 LONE PARENT TAMILIZS: The Economic Challenge (1990)

(81 8904 1) ISBN 92-64-13303-8, 252 pp. $\quad £ 20.00 \quad$ U\$\$34.00 FF160 DM66

\section{EMPLOYMENT}

OICD IMPLOMANT OUTLOOK July 1990 (published annua1ly)

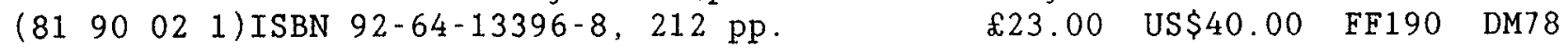

THE INTEGRATION OF WONEN INTO THE ICONOMY (1985)

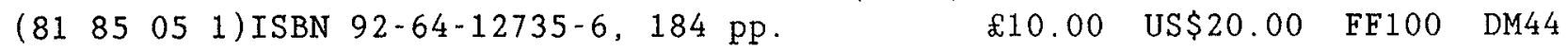

MEASURES TO ASSIST THE LONG-TERM UNMMPLOYED -- Recent Experience in SOMe OECD Countries (1988)

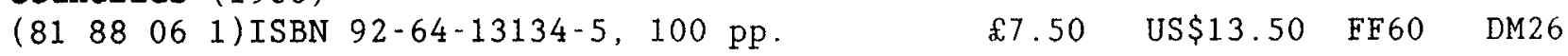

IABOUR MARKWT ILEXIBILITY: Trends in Entexpxises (1989)

(81 8903 1) ISBN 92-64-13286-4, 74 pp.

$£ 10.00$ US\$17.00 FF80 DM33 
MACEANISMS TOR JOB CRFATION: Lessons from the United States (1989)

(81 8801 1) ISBN $92-64-13186-8,228 \mathrm{pp} . \quad £ 14.50$ US\$25.50 FF120 DM50

NEW TECENOLOGY IN THE 1990S: A SOcio-zconomic StrategY (1989)

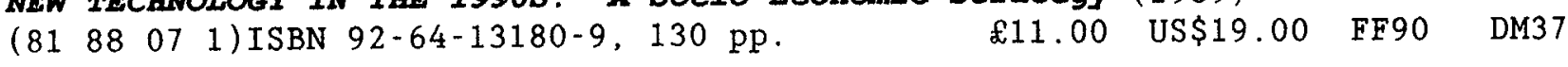

LABOUR MARKET POLICIES TOR THE 1990s (1990)

(819001 1)ISBN 92-64-13363-1, $130 \mathrm{pp}$.

$£ 13.00$ US\$23.00 FF110 DM43

\section{DEMOGRAPHY}

AGEING POPULATIONS: The Social Policy Implications (1988)

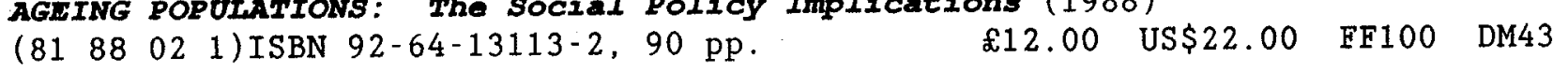

\section{CHILD CARE}

CHIIDRIN AND SOCIFTY: Issues for Pre-School Reforms (1981)

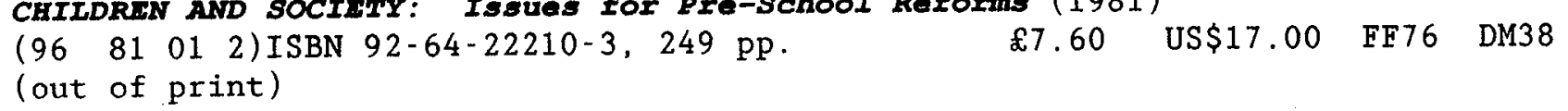

CARING TOR YOUNG CHILDREN (1982)

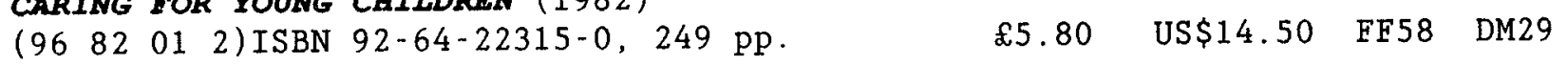
(out of print)

"CHILD CARE IN OECD COUNTRIES", in OrCD Employment Out1ook, July 1990, chapter 5 .

Prices charged at the OECD Bookshop

THE OECD CATalogur or PUBLICATIONS and supplements will be sent

free of charge on request addressed either to OECD Publications Service,

2, rue André-Pascal, 75775 PARIS CEDEX 16

or to the OECD Distributor in your country 
The size, structure and growth of health and pension programnes have. in recent years, been matters of concern to all OECD governments and societies. At issue are not only currently important social and economic questions, but also future difficulties which are likely to arise with the ageing of OECD population structures.

Japan has the fastest ageing population structure in the OECD. In 1960 the proportion of the population aged 65 and over in Japan was 5 per cent. In 1985 this proportion was 10 per cent, and in 2000 it is projected to be 15 per cent. The resulting pressures on social programmes are well understood in Japan, and the way in which the Japanese government and people are approaching this issue is of interest to other countries which must soon face similar problems.

This paper, which describes the Japanese health and pension systems. their recent developments and their reform in the face of this rapidly ageing population structure, was prepared in OECD's Directorate for Social Affairs. Manpower and Education. It is taken from two reports written by the Japanese Ministry of Health and Welfare which were contributions to a conference on health and pension policies in the context of demographic evolution and economic constraints, organised jointly by the Japanese authorities and the OECD. The reforms discussed in the paper occurred in the mid-1980s and it should be noted that the data used are also of that period.

La structure et la croissance des systèmes de santé et de retraite sont devenues depuis quelques années un sujet de préoccupation pour les pouvoirs publics et les sociétés des pays de 1'OCDE. Il s'agit non seulement de grands problèmes économiques et sociaux, mais aussi et surtout des difficultés qui risquent de surgir à 1 'avenir du fait du vieillissement démographique.

De tous les pays de 1'OCDE, c'est le Japon qui connaît le vieillissement le plus rapide de sa population. En 1960, la part de la population âgée de plus de 65 ans par rapport à la population totale y était de 5 pour cent. En 1985 cette part était passée à 10 pour cent et, selon les projections, elle se situera aux alentours de 15 pour cent en l'an 2000 . Les pressions qui s'exerceront sur les programmes sociaux ont été bien comprises par les Japonais, et les politiques adoptées par le gouvernement pourraient servir d'exemple aux pays qui connaîtront bientôt les mêmes problèmes.

Ce rapport décrit les systèmes de santé et de retraite au Japon, leur. évolution récente et leur réforme face au vieillissement rapide de la population. I1 a été préparé à 1'OCDE par la Direction des Affaires sociales. de la Main-d'oeuvre et de 1'Education. Il est tiré de deur rapports rédigés par le ministère japonais de la Santé et de la Protection sociale pour la Conférence sur les politiques de santé et de retraite face aux contraintes économiques et démographiques, conférence organisée conjointement par les autorités japonaises et 1'OCDE. Les réformes soumises à discussion dans ce. rapport se sont produites dans le milieu des années 80 . Les statistiques utilisées concernent aussi la même periode de reference. 



\section{PREFACE}

Health care services and old-age retirement pension programmes are now the two largest components of public expenditure in most advanced economies. Each year OECD governments spend over US\$ 1000 billion in protecting the health of their citizens and in providing incomes for their retirement. This is a large amount of money. Averaged across the OECD area, it is approaching half of total public outlays, some 25 per cent of GDP. Health care programmes alone absorb over 7 per cent of GDP and employ about 5 per cent of the total labour force. Social security pensions account for around 15 per cent of household disposable incomes and are the sole means of support for a significant proportion of the population.

Health and pension programmes are not only large, they have also been growing very rapidly. In money terms, outlays on these two items are now 25 times what they were in 1960 . In real terms, expenditures have grown by an average of nearly 7 per cent per annum over the last thirty years, about twice the growth rate of real GDP.

Social undertakings on this scale, particularly when they grow as rapidly as these two programmes have, inevitably cause problems for public budgets and have important implications for the private sector. During the $1970 \mathrm{~s}$, in the context of an enlarged welfare state, slower economic growth, and a well developed momentum of expansion in both health services and pension schemes. financing problems were encountered and public deficits widened. In 1970 the public budgets of the seven major economies were in small surplus. By 1975 this surplus had turned into a deficit of nearly 4 per cent. Nearly half this decline was accounted for by the growth of expenditure on health and pensions, and was accompanied by high inflation and mounting unemployment. In these circumstances it is not surprising that governments sought to bring the growth of social expenditures under control. And they did so with some success. In 1985, for the first time in thirty years, the growth of real social expenditures, averaged across the OECD countries, fell below that of real GDP. But the central issue - - that of overall restraint on public commitments to health and pension schemes - remains a permanent concern of budgetary planners.

The future age structure of OECD populations is particularly relevant to the future management of health and pension programmes. Current population projections indicate that in the first quarter of the next century the number of old people in OECD countries will increase rapidly. More importantly and more precisely: the number of people over the age of 65 (who are presumed to be dependent for their support on the rest of the population) will increase much more rapidly than the number of people of working age (those between 15 and 64 years of age) who are presumed to be the chief source of support for the young and the elderly. At the present time, on average across OECD countries, there are about five and a half people of working age for each person over 65. By 2025, this figure will have dropped to about three and a quarter. 
of course there are all sorts of qualifications to be attached to this generalisation. The rate and timing of demographic change differs between countries and there are some uncertainties about future death rates and even greater uncertainties about future birth rates. In drawing out the consequences of this picture there are many different versions of what the world might be like in forty years time.

But some of the implications of these projections seem clear:

- In the first place, the basic story about the ageing process seems robust. Assumptions about birth rates, death rates and migration may vary and are subject to margins of error, but those people who are going to be over 65 in the year 2025 have already been born and so have most of the workers who will support them. To assume that, left alone, the ageing problem might disappear would require extremely implausible assumptions about the course of future birth and death rates. The risk is rather the other way round. Life expectancies might improve more than anticipated, or birth rates continue to decline. Such developments would worsen rather than improve the ageing problem.

- Second, we know that we would face severe problems if we were to allow public health and pension support for old people to grow in line with the health programmes and real incomes of the rest of the community. (That is, maintain a constant relative position.) Contribution rates would need to double, or very nearly, and would place considerable strain on the revenue base and taxable capacity of most OECD economies.

- Third, we are aware that some, probably most, existing health and pension systems contain promises of improved relative levels of support. In some pension systems this is explicit in the way the systems are intended to mature. In most health systems it is implicit in the commitment to provide best-practice health care to all sections of the population in a climate of costly technology. increasing utilisation and a concentration of illness patterns on chronic and long-term care of the aged.

- Finally, it is a political, administrative and technical fact that changes to health and pension schemes take a long time to introduce, to become effective and to permeate the system. This is not only a technical question (for example, the long lead-times embodied in earnings-related pension schemes), but also a reflection of the time required to form the political and social consensus necessary to change expectations and implement reforms.

During the next fifteen to twenty years many OECD countries will enjoy a respite from the pressures of demographic ageing. Nevertheless, there is concern regarding the inevitability of the arrival of the ageing process and an awareness that if the problems are to be tackled effectively, policies must be adjusted now. Among other things, this means persuading policy makers to adopt longer time horizons than is usually the case. 
Japan is an important exception to this general pattern. Japan is already facing an ageing process which is causing immediate and serious problems. Japan has the fastest ageing population structure in the OECD. In 1960 the proportion of the population aged 65 and over in Japan was 5 per cent. In 1985 this proportion was 10 per cent, and in 2000 it is projected to be 15 per cent. The resulting pressures on social programmes are well understood in Japan, and the way in which the Japanese government and people are approaching this issue is of interest to other countries which must soon face similar problems.

The two chapters in this report describe the structure of Japanese health and pension systems, their recent development and their reform in the face of the ageing pressure.

The Japanese health care system is characterised by two main features: collective financing of health care services by a combination of employmentbased and government-subsidised insurance schemes; and private provision of the health services themselves. There are three different schemes which cover employees, the self-employed and retirees, and the aged. A separate social service system provides for the medical needs of the poor. Although health expenditures in Japan are below the OECD average as a share of national income, spending has more than doubled since 1960, going from 3 per cent in that year to 6.6 per cent in 1986 . Over the same period government subsidies more than doubled, from 15 per cent of all spending to over 30 per cent, and direct patient payments fell from 30 to 12 per cent of total outlays.

Much of the increase in government support has resulted from financing inadequacies in the health insurance programme for the self-employed, retirees and the aged, as well as deliberate government action taken in the early 1970 s to reduce cost-sharing for the elderly. In the past few years major reforms in both financing and cost-sharing have been undertaken to reduce the growing dependence of the health insurance funds on National Government subsidies. The principal reforms have focused on shifting the costs of the least solvent insurance funds for the self-employed, retirees and the aged to the financially stronger employee health insurance funds, and on using cost-sharing as a financing and demand control device. Reform activities on the supply side, in terms of planning and reimbursement reform, are also being considered. In addition, the Japanese have placed a strong emphasis on health prevention and promotion activities.

Old age. survivors and disability pensions in Japan were, until recently, provided by three main schemes: the Employees Pension Insurance (EPI), the National Pension Scheme (NPS), covering the self employed and dependent wives, and a smaller group of Mutual Aid Associations (MAAs), the most important of which covered government employees. The EPI was of the social insurance type, with benefits related to contributions - . the latter being split equally between employer and employee. The NPS had a structure based on flat-rate contributions and benefits. 
During the early 1980's Japan introduced major pension reforms - the only major pension reforms in the OECD area in recent years. These reforms required difficult technical planning and a considerable amount of social and political consensus for their adoption. Briefly, the reform has involved bringing the schemes together, thus giving all employees a pension with an earning-related component and a flat-rate component. A key element of the reform is that the current replacement rate (68 per cent) will be maintained as the system matures. Without the reform, the replacement rate would have increased to 83 per cent, and in some cases the replacement rate for households with double entitlements would have reached 109 per cent. There are a number of remaining problems and the reform process is not yet over. 


\section{PART I - HEALTH REFORY}

I. THE PRESENT SYSTEM: OUTLINE

1. Health Insurance System

2. Medical Care Delivery System 8

II. REFORM IN THE HEALTH INSURANCE SYSTEM AND FUTURE PROSPECTS 11

3. Recent Trends in National Medical Care Expenditure 11

4. Reform of Health and Medical Services for the Aged 14

5. Reform of the Health Insurance System 15

6. Future Policies 18

III. HEALTH PROMOTION AND HIGH-QUALTTY MEDICAL CARE 19

7. Comprehensive Health Promotion 19

8. Toward Improved Medical Services 21

PART II - PENSION REFORM

$\begin{array}{lr}\text { INTRODUCTION } & 25\end{array}$

I. PRESENT SITUATION OF PUBLIC PENSION SYSTEM AND PROBLEMS 26

1. Present Situation of Public Pension System 26

2. Changes in Socio-Economic Environment 30

3. Problems of the Public Pension System 34 
II. REFORM OF THE PUBLIC PENSION SYSTEM

4. Reorganisation of the System with the Introduction of Basic Benefit

5. Rationalisation of Benefits and Liabilities

6. Improvement of Pension Protection for Women and the 45 Disabled

7. Issues for Further Examination

III. THE PRESENT SITUATION OF OCCUPATIONAL PENSIONS

8. Occupational Pension Provisions

9. Problems of Occupational Pensions 
part 1

\section{HEALTH REFORM IN JAPAN}

I. THE PRESENT SYSTEM: OUTLINE

\section{THE HEALTH INSURANCE SYSTEM}

The Japanese health care financing and delivery system is complex. reflecting Japan's historical and economic development. The current Japanese health system traces its roots back to the 1870 s with the establishment of a modern system of public health administration based on the German medical system. Social insurance protection for workers began in 1922 and evolved in much the same way as other European social insurance systems so that by 1961 health insurance protection had been extended to the entire population. Following the Second World War the Japanese health care delivery system was strongly influenced by the American medical system.

Today, there are more than 100 national laws governing health and medical matters in Japan, under the responsibility of the Ministry of Health and Welfare. The Ministry's activities span the entire range of public health, social welfare, health care financing, and pension matters including: disease prevention, environmental health, manpower training, quality assurance, delivery system control, direct service provision, narcotics control. pharmaceutical affairs, biomedical research, social protection, provision and administration and implementation of social insurance programmes. Prefectural and local governments also have important roles in the financing. administration and delivery of public health services, social welfare, and the health services provided through the social insurance system.

Most medical services in Japan are provided through a universal heath insurance system. which is employment and community and covers all employees. self-employed individuals, and dependents, as well as retirees and the elderly. It is financed on the basis of individual contributions. employer contributions and government subsidies. This system accounts for about 90 per cent of all medical care expenditure in Japan. In addition, a public assistance scheme based on the Public Assistance Law of 1950 pays for medical care as well as other social services for needy persons, subject to a means test. This scheme. which is funded entirely by national and local government contributions. accounts for about 5 per cent of all medical care expenditure. Lastly. public funding also pays for care for specific diseases and disorders such as tuberculosis, nuclear irradiation and mental illness, which are also funded entirely by national and local government and which account for about 3 per cent of all medical expenditure. The remaining 2 per cent of expenditure results from direct patient payments for services not covered by insurance. 
Table 1 provides a detailed description of the various medical insurance schemes comprising the Japanese health insurance system. In general these schemes can be divided into:

i) Employee Health Insurance for employees and their family members; and,

ii) National Health Insurance for self-employed individuals, farmers, retirees, and their family members.

There is also a special system for all aged members of the various schemes known as Health and Medical Services for the Aged, which provides additional benefits to the aged. While there are major similarities in these systems in terms of medical services covered and reimbursement procedures for medical care providers, there are significant differences in eligibility. administration, cost-sharing, cash benefits, financing and the level of national subsidy.

\section{Employee Health Insurance}

\section{a) Eligibility and administration}

Health insurance for employees and family members is subdivided into seven different types of programmes. The two largest are Government Managed Health Insurance and Society Managed Health Insurance, the former being aggregations of employees of smaller firms whose insurance is administered by the national government, while the latter are generally employees of large firms (i.e. more than 300 employees employed by one or more employers) whose insurance is administered by a separate corporate body of those firms. The remaining five types of Employee Health Insurance schemes include two targeted to Seamen and Day Labourers and administered by the national government, and three Mutual Aid Association Insurance schemes representing civil servants and private school teachers and employees which are administered by the Mutual Aid Associations.

\section{b) Benefits and cost-sharing}

A11 seven Employee Health Insurance schemes cover the costs of an extensive range of medical benefits including medical consultations, medical goods such as pharmaceutical and therapeutic appliances, general treatment, surgery, therapy, hospitalisation, hospital nursing, and transportation. There is a 10 per cent cost-sharing for employees while dependents face 20 per cent cost-sharing for inpatient services and 30 per cent cost-sharing for outpatient services. There is also a ceiling on out-of-pocket costs covered under the "Costly Medical Expense Benefit" of $¥ 51000$ per month per person ( $¥ 30000$ for low income persons) with lower limits for households and patients suffering from specific costly diseases. Cash benefits in the form of injury and sickness allowances, maternity allowances, delivery expenses and funeral expenses are also provided under all seven schemes. However, Society Managed Health Insurance and Mutual Aid Association schemes can, at their option. provide additional cash or medical benefits (e.g. filling in cost-sharing). 


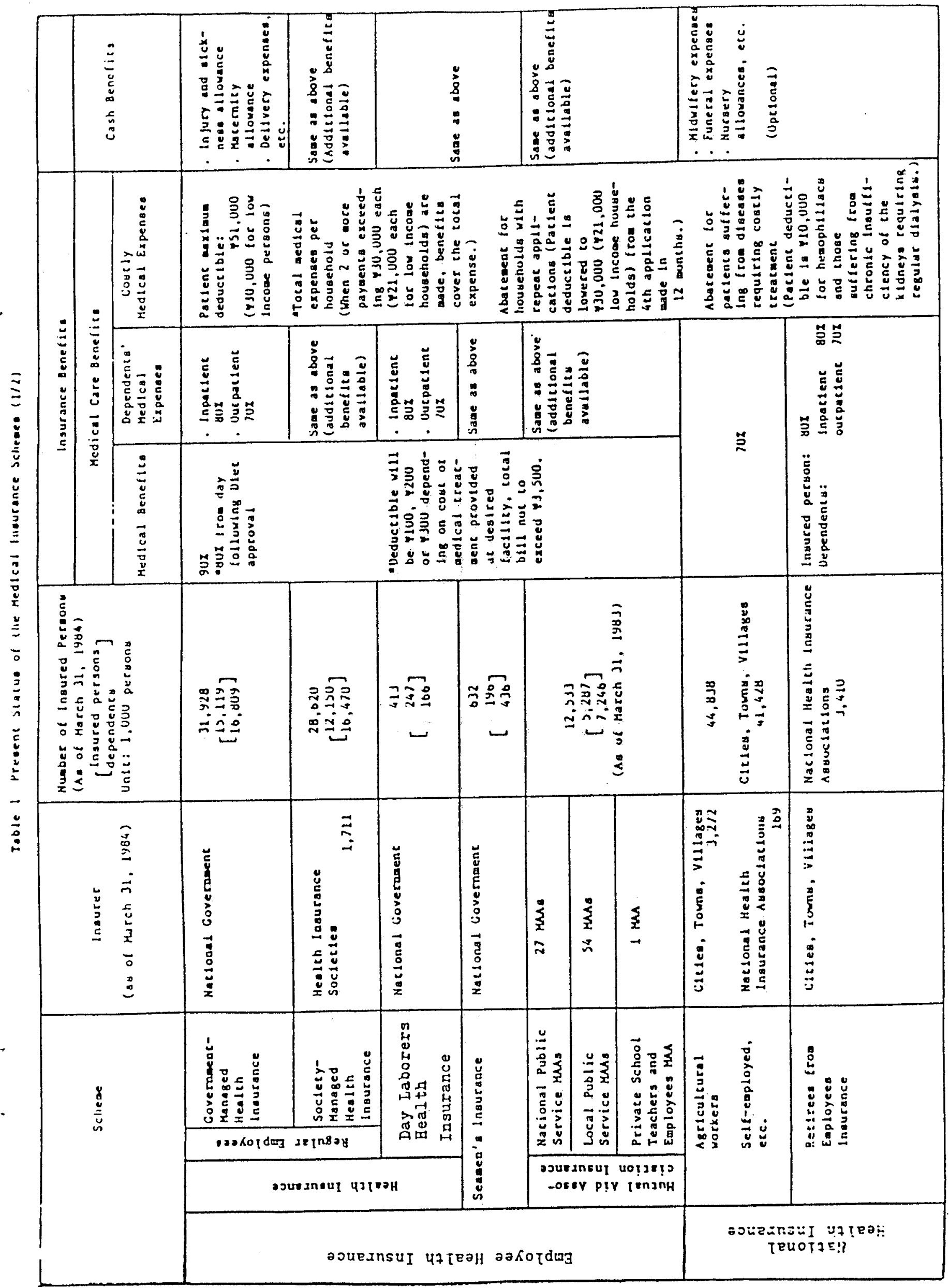

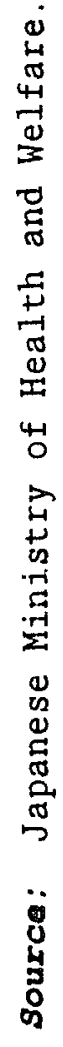




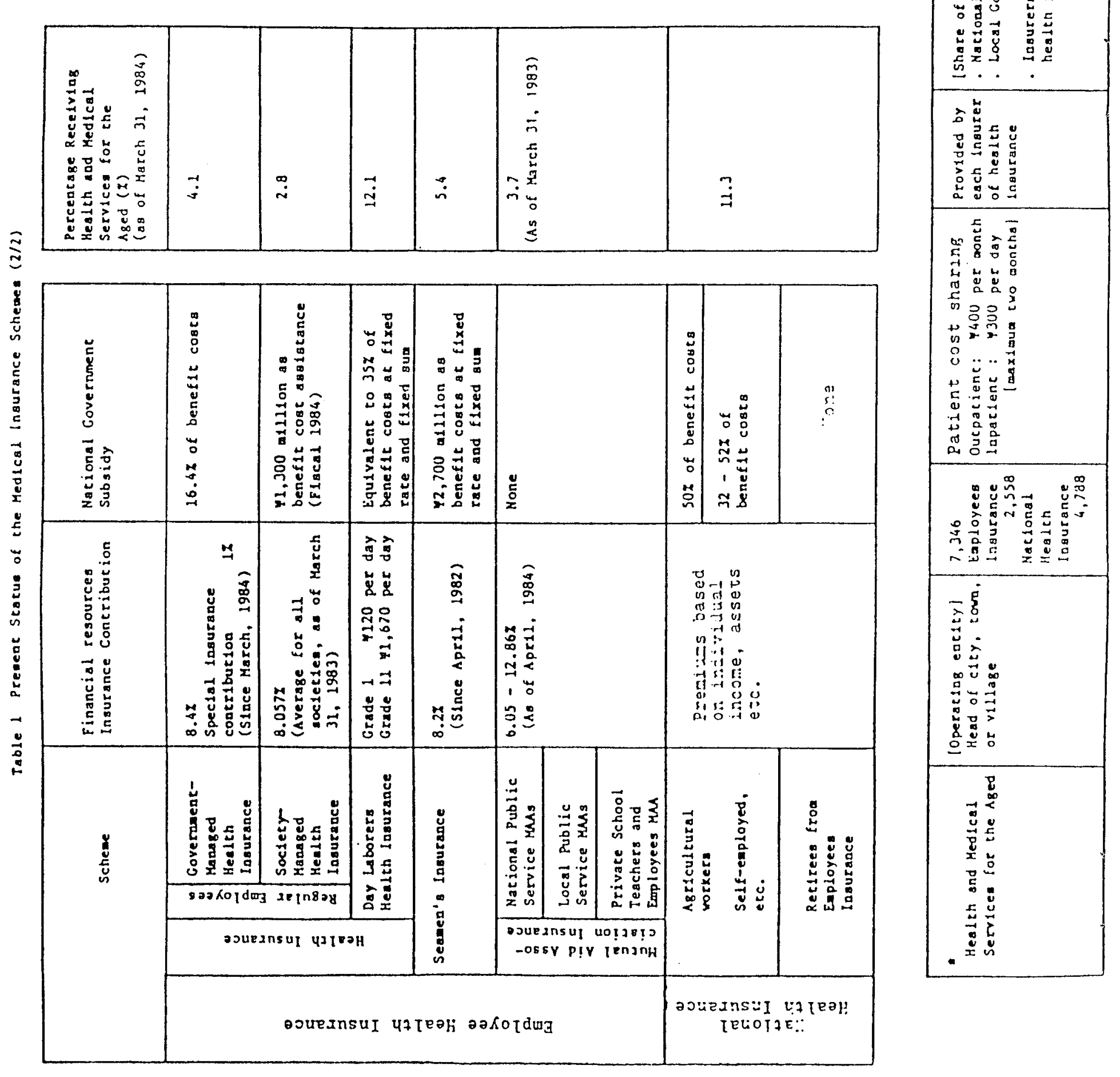




\section{c) Financing and national government subsidy}

All seven schemes are financed by premium contributions based on earnings and generally are shared equally between employee and employer. Premium rates vary between 6 and 13 per cent. National government subsidies for benefit costs are relatively small (i.e. $¥ 1300$ million or less than 1 per cent for Society Managed Health Insurance, 16.4 per cent for Government Managed Health Insurance). Subsidies are related to the financial structure of each fund which is a function of its income (e.g. its earnings base) and its expenditures (e.g. age structure, medical risks, etc.). The national government generally pays for the administrative costs of all seven schemes. The average national benefit subsidy for all Employee Health Insurance schemes is less than 10 per cent of expenditures.

\section{d) Reimbursement}

Patients seeking care present their health insurance membership card to any participating (virtually all) clinic or hospital. Payment to the facility is on a fee-for-service basis. The remuneration for each insurance-covered medical treatment is established by the Minister of Health and Welfare and based upon the deliberations of the Central Social Insurance Medical Council. The Council consists of six representatives of employers, six representatives of medical care providers and three representatives of public interest groups.

Reimbursement is based on a "Points Unit Cost Schedule" which lists the number of points designated for each medical care item and the given value per point (i.e.a relative value schedule and a multiplier). Specifically, remuneration equals the sum of the points for each medical service rendered to the patient times the given unit value (currently $¥ 10$ ). Medical institutions and physicians are reimbursed the calculated remuneration less the requisite patient cost-sharing directly from a Medical Care Fee Payment Fund. The same payment schedules and procedures are used for all insurance programmes as well as medical reimbursements made through public assistance. No billing of patients for amounts in excess of the rates established by the schedule is permitted.

\section{National Health Insurance}

\section{a) Eligibility and administration}

National Health Insurance is community based health insurance which covers those not eligible for Employee Health Insurance, in particular agricultural workers, self-employed individuals, and retirees, as well as their dependents. It is subdivided into two somewhat different schemes, one for agricultural workers and self-employed individuals, and a second scheme, created in 1984, for retirees (e.g. retired workers under age 70 and disabled retirees under age 65 except those covered as dependents under ancther scheme). National Health Insurance is generally administered by cities, towns or villages but in a number of cases is administered by National Health Insurance Associations which are private bodies representing specific trades or professions. 


\section{b) Benefits and cost-sharing}

The medical care services covered are generally the same as those for Employee Health Insurance. However, the cost-sharing is higher. Except for retirees and their dependents, individuals covered under National Health Insurance have 30 per cent cost-sharing. Retirees face 20 per cent cost-sharing and their dependents face the same 20 per cent cost-sharing for inpatient care and 30 per cent for outpatient care as dependents covered under Employee Health Insurance. Nevertheless, total out-of-pocket costs through cost-sharing are limited by the "Costly Medical Expense Benefit" which provides individuals covered under National Health Insurance with the same ceiling for out-of-pocket medical payments as those covered under Employee Health Insurance. Cash benefits are usually somewhat more limited than those provided under Employee Health Insurance.

c) Financing and national government subsidy.

Prior to 1984 financing for retirees and other individuals covered under National Health Insurance was the same. Financing was based on premiums related to the individual's income, assets, etc. and subsidies from the national government. In 1982 the national government subsidy covered about 45 per cent of benefits compared to less than 10 per cent on average for Employee Health Insurance. The national government also paid for the cost of administration. The average annual contribution level under National Health Insurance was $¥ 101329$ per household in fiscal year 1982 compared to $¥ 187959$ per household insured under Government Managed Health Insurance (shared equally by employee and employer) and $¥ 238650$ per insured under Society Managed Health Insurance (shared equally by employee and employer). In 1984 special financing for the retiree scheme was introduced. While the individual premium contribution for retirees was retained, the former national government subsidy was replaced by contributions from the Employee Health Insurance schemes. In particular, the costs of the retirees in excess of premium contributions are now financed from the various Employee Health Insurance schemes based on a formula which relates each schemes contribution to its total earnings base. This change has reduced the national government subsidy for National Health Insurance to 40 per cent.

\section{d) Reimbursement}

The payment levels and reimbursement procedures for National Health Insurance are the same as those for Employee Health Insurance.

\section{Health and Medical Services for the Aged}

\section{a) Eligibility and administration}

This insurance scheme covers persons 70 years old and over and disabled persons aged 65 to 69, who are covered under an Employee Health Insurance scheme or National Health Insurance. The scheme is administered by cities, towns or villages. 
Chart 1

OUTLINE OF HEAL.TH INSURANCE SYSTEM

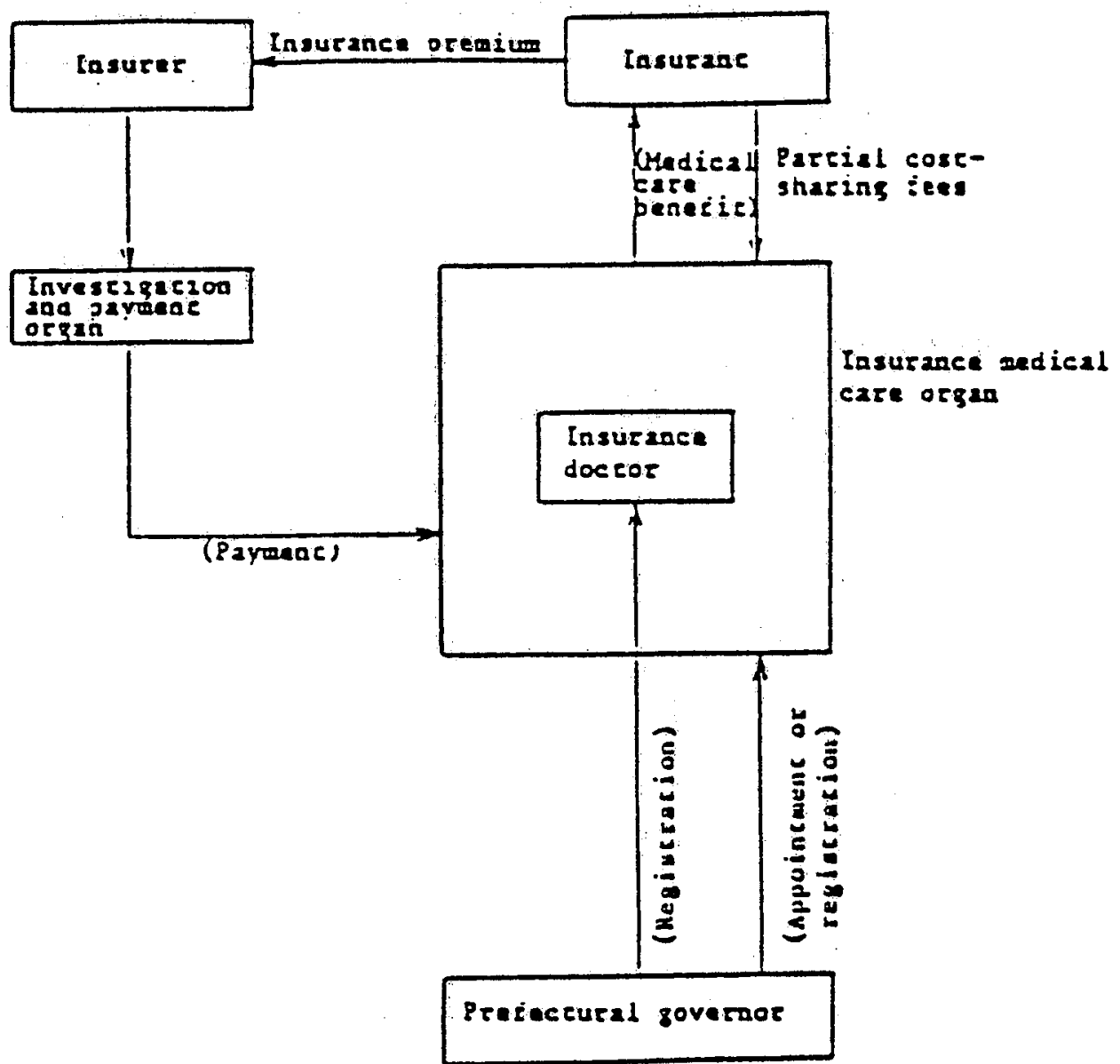

Source: Japanese Ministry of Health and Welfare. 


\section{b) Benefits and cost-sharing}

The Health and Medical Services for the Aged programme covers the whole range of medical benefits with a substantial reduction in cost-sharing. Under this programme, cost-sharing is $¥ 400$ per month for outpatient care and a $¥ 300$ per day for hospital care (for a maximum of 2 months). Individuals also receive any additional medical benefits and the full range of cash benefits which are covered by the Employee Health Insurance or National Health Insurance scheme to which they belong (e.g. aged individuals who are retired would continue to belong to National Health Insurance, while aged individuals still working would belong to their pertinent Employee Health Insurance or National Health Insurance scheme).

\section{c) Financing and national subsidy}

Medical care expenditures are financed through national government contributions ( 20 per cent), local government bodies ( 10 per cent, equally divided between prefectural and city, town or village governments), and other insurers ( 70 per cent). Prior to 1983, before the Health and Medical Services for the Aged was implemented, the financing of each insurer was based on the costs incurred by the elderly subscribers in each insurer's scheme. This resulted in large disparities in financing across schemes, since, as shown in Table 1, the elderly are unevenly distributed across the various schemes. For example, 11.3 per cent of National Health Insurance subscribers are elderly compared to 2.8 per cent for Society Managed Health Insurance and 4.1 per cent for Government Managed Health Insurance. Currently, the 70 per cent financing share of other insurers is divided among these insurers in such a way that the burden-sharing imbalance otherwise generated among them by differences in the percentage of elderly subscribers is corrected.

\section{d) Reimbursement}

Reimbursement procedures for the aged are generally the same as those employed for Employee Health Insurance and National Health Insurance schemes. However, a different "Points Unit Cost Schedule" has been developed for medical services provided to the elderly. The points for each medical procedure were designed to appropriately reflect the care needs resulting from the physical and mental characteristics prevalent among the elderly. The objectives of the new schedule are: to eliminate unnecessarily long hospitalisations by promoting home and community based care, to promote cognitive guidance for daily living in order to reduce overuse of medications, and to adjust hospital fees to appropriately reflect the needs of chronic versus acute care patients.

\section{MEDICAL CARE DELIVERY SYSTEM}

National and local governments play a fundamental role in the medical care delivery system. They are responsible for licenser, quality assurance. planning, direct service provision, and medical education. Except for national hospitals, prefectural governments license hospitals and assure that they meet all legal standards. Inspectors periodically check hospitals to ensure compliance with established standards. While planning in terms of public hospital bed needs is done at the local level, there are no controls over the expansion of private hospitals. Governments at all levels provide 
services directly through national and public hospitals, community health centres, mental health clinics, etc. in fulfilling the public health and social assistance roles of government. The government operates over 50 medical schools, with at least one in each prefecture and establishes educational and training standards for nurses, midwives and other health professionals.

Complementing the government's functions vis-à-vis the medical care delivery system is the important role played by the private sector. Most care, outpatient and inpatient, is delivered by private practitioners in hospitals or clinics (clinics can be strictly ambulatory treatment centres and/or facilities with less than 20 beds). The medical care delivery system in Japan is also characterised by private ownership of most medical care facilities.

\section{Medical Care Facilities}

a) Hospitals

Table 2 displays the numbers of hospitals, hospital beds, and average number of beds per unit by ownership status for 1983. Almost 80 per cent of the 9515 facilities and 63 per cent of the 1.4 million beds were privately owned. Hospitals are classified as General Hospitals, Mental Hospitals, Leprosaria, Hospitals for Tuberculosis, and Hospitals for Contagious Diseases.. General Hospitals account for over 88 per cent of the facilities and over 70 per cent of the beds. Besides hospitals, general clinics contribute another 285000 beds, 97 per cent of which are privately owned. The total number of hospital beds (including clinics) increased 24 per cent from 1388586 in 1973 to 1726213 in 1983. Over this period the number of hospital beds per 100000 has increased 16 per cent from 1035 to 1206.

Table 2

OWNERSHIP CHARACTERISTICS OF HOSPITAL BEDS \& UNITS

(1983)

Hospitals

National Other Public Private

Total

\begin{tabular}{|c|c|c|c|c|}
\hline Number $(\%)$ & $\begin{array}{r}442 \\
(4.6)\end{array}$ & $\begin{array}{r}1506 \\
(15.8)\end{array}$ & $\begin{array}{r}7567 \\
(79.5)\end{array}$ & $\begin{array}{l}9515 \\
(100)\end{array}$ \\
\hline $\begin{array}{c}\text { Number of beds } \\
(\%)\end{array}$ & $\begin{array}{r}166 \quad 162 \\
(11.5)\end{array}$ & $\begin{array}{r}364346 \\
(25.3)\end{array}$ & $\begin{array}{r}909873 \\
(63.2)\end{array}$ & $\begin{array}{r}1440381 \\
(100)\end{array}$ \\
\hline $\begin{array}{l}\text { Average number of } \\
\text { beds per unit }\end{array}$ & 375.9 & 241.9 & 120.2 & 151.4 \\
\hline
\end{tabular}

Source: Japanese Ministry of Health and Welfare. 
In the past, within the hospital sector there was virtually no distinction between acute and chronic care hospitals. Patients with chronic conditions were generally treated in hospitals and clinics. Starting in 1983. special staffing requirements and a different "Points Unit Cost Schedule" were established for hospitals treating large numbers of the aged with chronic conditions. However, the use of nursing homes and intermediate care facilities as parts of an integrated medical-social service system is still not well developed in Japan, although it is an area of current reform. For publicly owned hospitals, investments in capital are made by the national government. For privately owned hospitals capital expenditure must be met through fee-for-service reimbursements, although public loan schemes for initial capital costs are available.

For a hospital to be established, a permit from the prefectural government is required, and the permission will be given only to non-profit hospitals. For public facilities (prefectural, city, towns, villages, etc.), an approval will not be granted if the additional capacity would result in exceeding established hospital total bed targets. There is no such prohibition on the establishment of private facilities as long as they meet the general certification requirements (e.g. staffing, equipment, etc.) stipulated in the national Medical Supply Law.

\section{b) Clinics}

At the end of 1983 there were 78991 general clinics and 43115 dental clinics. Thirty-four per cent of general clinics contained patient beds. Ninety-three percent of general clinics and 99 per cent of dental clinics are privately owned. Physicians and dentists can establish clinics by notifying the prefectural government. For others to establish a clinic, approval of the prefectural government is required, and the approval will be given only to non-profit clinics.

\section{Medical Care Personne1}

\section{a) Physicians}

At the end of 1982 there were 167952 physicians in Japan or 141.5 per 100 thousand people up from 126237 physicians and 116.2 per 100 thousand in 1973. Over 95 per cent of all physicians practice in facilities (i.e. hospitals or clinics), and the predominant form of delivery for ambulatory as well as hospital care is in physician-owned and directed free-standing clinics or hospitals.

Forty per cent of all physicians own facilities. Furthermore, pharmaceutical and physician practices are usually combined, so that patients can obtain pharmaceuticals at the facilities where they get medical services. Solo practice is the overwhelmingly prevalent model of practice for private practitioners.

\section{b) Qther medical personnel}

In addition to physicians, there are 21 other types of medical care personnel recognised in statute. These included dentists (58 362 or 49.2 per 100 thousand people), working nurses and assistant nurses $(573650$ in hospitals and clinics) and midwives (26 603). 
As to other categories of the medical care personnel, physical therapists numbered 3911 , occupational therapists 1447 , orthopaedists 1045 (all three figures as of 1983), dental hygienists 24836 , dental technicians 26658 (as of 1982), radiology technicians 17262 , X-ray technicians 3943 , clinical laboratory technicians 33689 , and health laboratory technicians 2085 (as of 1981).

\section{REFORM IN THE HEALTH INSURANCE SYSTEM AND FUTURE PROSPECTS}

\section{RECENT TRENDS IN NATIONAL MEDICAL CARE EXPENDITURE}

The national medical care expenditure in 1982 was around $¥ 13865.9$ billion or about $¥ 117000$ per capita, equivalent to 6.55 per cent of national income.

Classified by origin, public funds from national and local governments accounted for 35.6 per cent, insurance contributions for 53.6 per cent, and payment by patients for 10.8 per cent.

The national medical care expenditure, which, in 1960 , before the implementation of nationwide comprehensive health insurance, had been $¥ 409.5$ billion, began to show rapid increases from the first half of the $1960 \mathrm{~s}$. Though the growth settled down to a one-digit percent increase after 1979, compared to an annual 20 per cent in the initial period, national medical care expenditure continued to grow by $¥ 1$ trillion annually.

The growth rate of national medical care expenditure was lower than that of the national income only in 1973; the former had been about double the latter from 1974 to 1976 , and ranging from equal to or double the latter since 1977. As a result, medical care expenditures in relation to national income have increased from around 4 per cent to 6 per cent (Table 3).

Estimates from the budget indicated that national medical care expenditure in 1985 will be $¥ 15720$ billion or $¥ 130000$ per capita, equivalent to 6.33 per cent of national income. The patients will be paying slightly more, with the introduction of a 10 per cent cost-sharing borne by the insured employee in the 1984 reform of the Health Insurance Law (to be explained later). The general tendency so far, toward a smaller burden for the patient and greater public funding, has been brought about by implementing nationwide comprehensive health insurance, raising benefit percentages, etc. (Chart 3).

to be:

The causes of the increase in medical care expenditure are considered

- The ageing population: greater numbers of aged persons susceptible to diseases and requiring longer periods of treatment.

- Evolution of the disease structure: higher occurrence rates for degenerative diseases requiring expensive medical care per individual, such as circulatory diseases (hypertensive diseases, etc.), newly discovered malignant organisms, and others. 


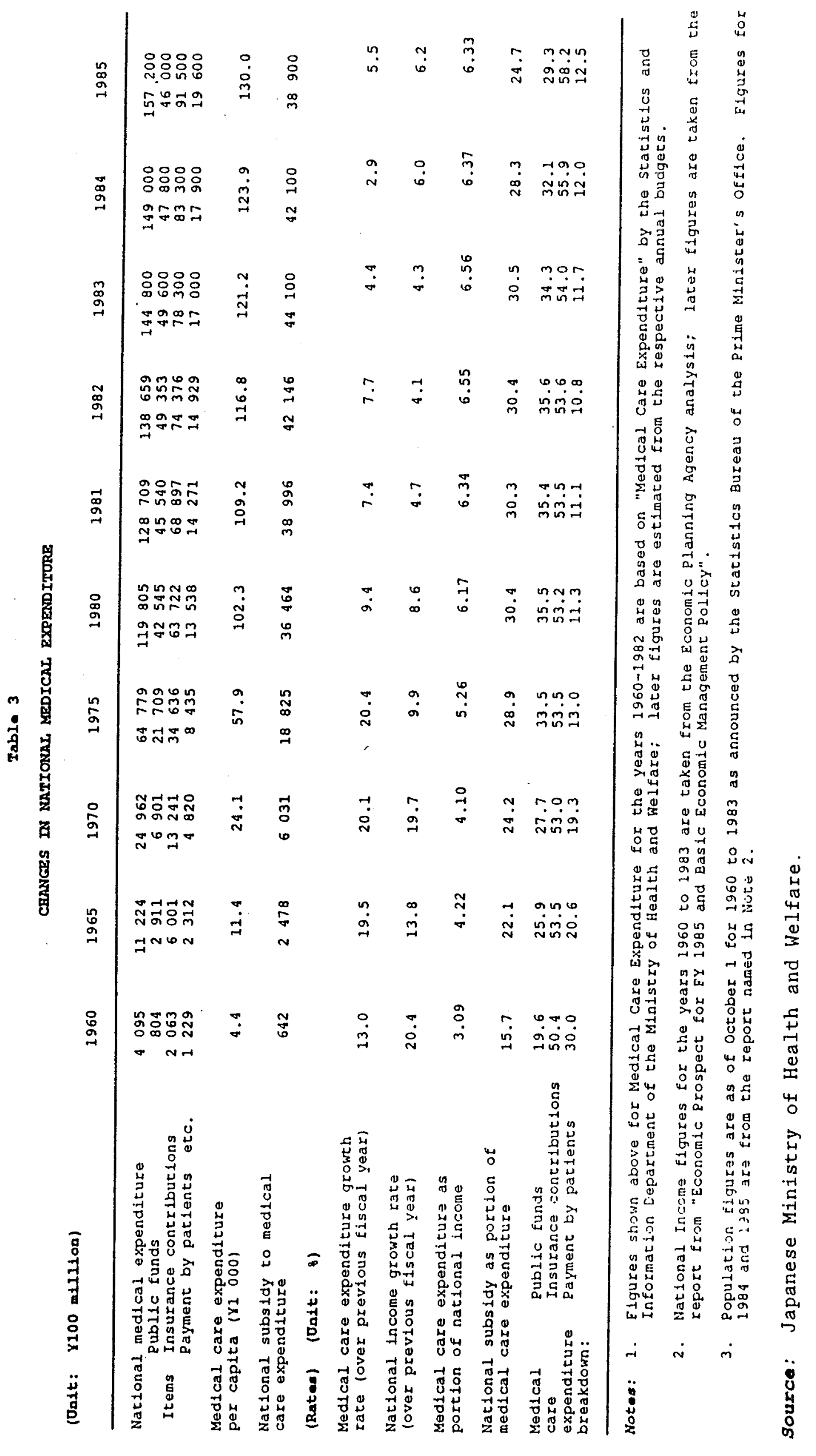


CHANGES IN NATIONAL MEDICAL CARE EXPENDITURE BY ORIGIN

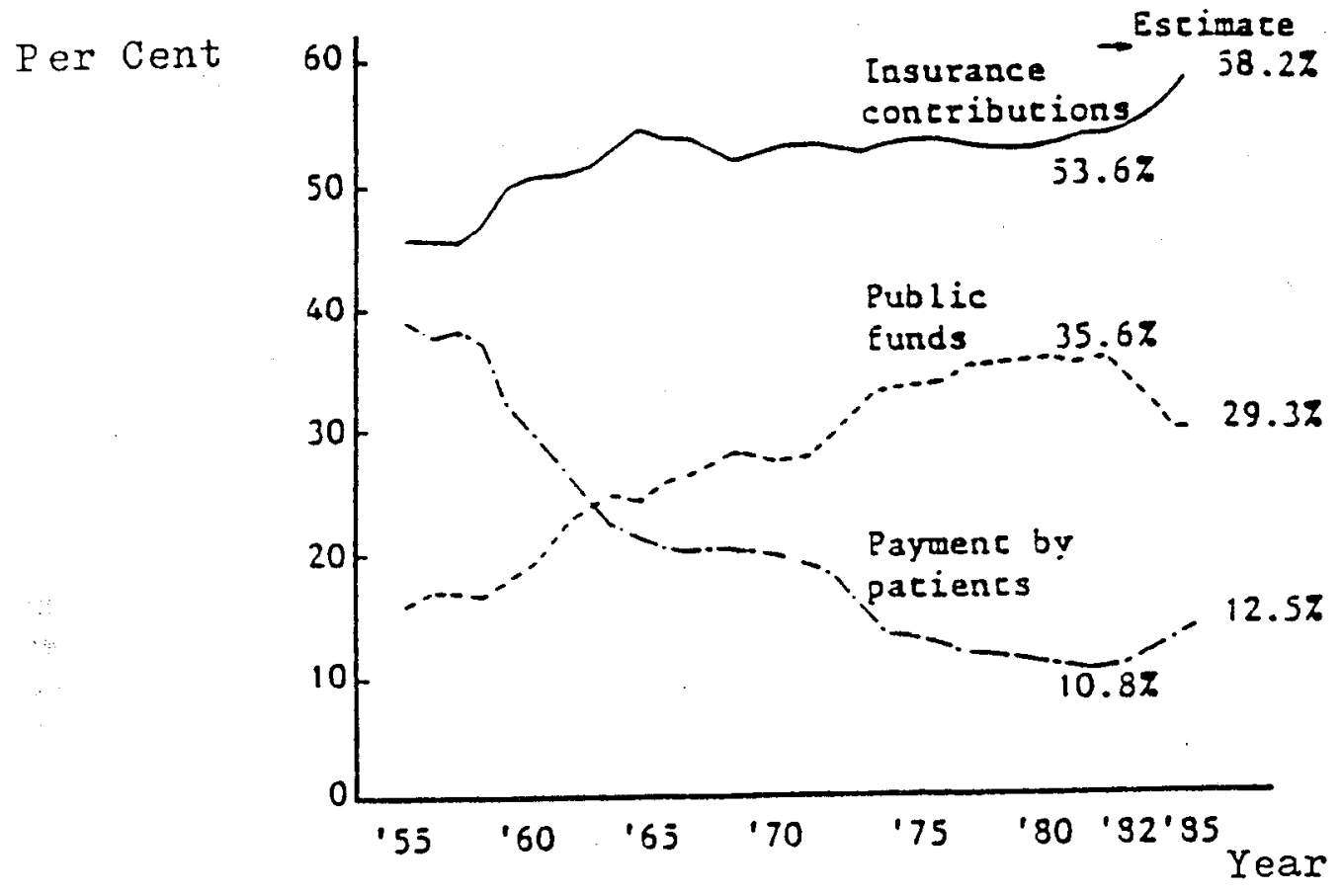

Source: "National Medical Care Expenditure", Statistics and Information Department, Ministry of Health and Welfare Estimate based on budget for 1983 to 1985 
- Development of medical technology: increase in costly diagnoses, examinations and treatments, resulting from the introduction of high-cost medical care equipment, popularised by the development of medical technology, to practices covered by health insurance.

The factors mentioned above are expected to persist, contributing to the tendency of the medical care expenditure to continue increasing over the long term.

\section{REFORM OF HEALTH AND MEDICAL SERVICES FOR THE AGED}

Japan has been actively reforming the health and medical services for the aged since 1973, mainly through the health insurance system embodied in the various health insurance laws and through the system for paying for the medical care costs for the aged as prescribed by the Law for the Welfare of the Aged.

The purpose of the grant system, which was enforced from January 1 . 1973 to January 31, 1983, in accordance with the Law for the Welfare of the Aged, was to facilitate access for aged people to comprehensive medical treatment, enabling them to maintain their health and to improve their welfare by financing, through public funds, the cost-sharing that was intended to be paid by them under the various health insurance schemes.

With the 1973 oil crisis which seriously affected economic growth, the national finance situation has become increasingly difficult. In this general setting, as the result of the ageing of the population, development of advanced medical care technology and the changing disease pattern, medical care expenditure for the aged continued to increase rapidly. Other problems came to the fore at the same time, including concentration of attention on compensation for medical care expenses, on the lack of integrated health and medical services from disease prevention to functional training, and on disproportionate distribution of medical care expenditure for the aged among the various health insurance systems, especially between Employee Health Insurance and National Health Insurance. The problems in the existing system led to an examination of the system from a long-term point of view. The conclusion was to devise a new structure that would ensure a fair distribution of medical care expenditure for the aged, as well as promote an overall integrated policy on health and medical services for the aged, including disease prevention and health promotion. The proposal materialised in the Law of the Health and Medical Services for the Aged, which came into effect on February 1, 1983 .

The Law has three main features:

a) The preceding "free medical service" system had been criticised because it weakened health awareness among the aged, who consulted doctors even for trivial problems, encouraged by the easy access to medical services. Taking this into consideration, the new Law set a monthly payment of $¥ 400$ in the case of outpatients, a daily $¥ 300$ for the first two months as partial cost-sharing in the case of inpatients (these apply to medical care recipients older than 70 and those aged 65 to 69 years old with a disorder who are covered by 
medical insurance). The purpose of this regulation is to direct the interest of the aged towards their own health, with the underlying notion that each should be responsible for his own health, and thus to establish a more adequate level of consultation with medical institutions.

b) The cost of medical care benefits borne by different insurers was changed in order to correct the burden-sharing imbalance of medical care expenditure for the aged among the various medical insurance systems. The Society Managed Health Insurance and Mutual Aid Associations, with lower rates of participation by the aged, now contribute a larger share, while the National Health Insurance, with a higher rate of aged persons, bears a smaller burden.

c) Distribution of health notebooks to citizens over 40 years old, health education, health consultation; health checks, functional training, visiting orientation, etc. have been implemented from the point of view of an overall policy covering disease prevention, treatment and functional training, and of complete health and medical service according to the age, physical and mental condition of the citizen.

\section{REFORM OF THE HEALTH INSURANCE SYSTEM}

\section{Objectives of Institutional Reform}

Though the annual $¥ 1$ trillion growth in national medical care expenditure in the late 1970 s had been to a certain degree suppressed since the establishment of the Law of the Health and Medical Services for the Aged in 1983, the necessity for a thorough revision of the existing health insurance system was widely acknowledged. Such revision was inevitable, if everyone was to receive equal access to quality services at a reasonable cost, backed by a stable management of the health insurance system, in the imminent "ageing society".

In view of this situation, the Government implemented health insurance system reform in 1984, which included an amendment to the Health Insurance Act. This amendment can be taken as a very important first step in the health insurance system reform, in that it was taken from the medium- and long-term perspective into the 21 st century. Along with the Law of the Health and Medical Services for the Aged which went into effect in February 1983, it points in the direction to be taken in formulating an ideal health insurance system for the future.

This institutional reform has two basic objectives. The first is to maintain medical care expenditures at an acceptable level now and in the future, a requisite for a stable health insurance system in the "ageing society" Japan is expected to become in the early 21 st century. Currently about 35 per cent of national income is used for taxes and social security, and this figure is expected to grow as the public pension plan matures concurrently with the ageing of the population. In this context, it is imperative to control the growth of medical care expenditure (keeping patient cost-sharing at the present level) in order to construct a stable health 
insurance system for the 21 st century. The second objective is to ensure a fair distribution of benefits and contributions between the various health insurance systems. The differences between these systems in both benefits and contributions should be reduced so that the health insurance system as a whole can continue to be treated as a social insurance institution.

With these two major objectives in mind, the items indicated below were selected as the three pillars for health insurance system reform:

- rationalisation of medical care expenditure;

- revision of health insurance benefits; and

- establishment of a fair distribution of health insurance burdens.

\section{Outline of the Reform}

\section{a) More rational and more effective medical care expenditure}

In addition to the various measures taken thus far, the following will continue to be implemented so as to promote more rational and more effective medical care expenditure:

- Rationalisation of medical fees, with greater emphasis on cognitive fees (doctors, etc.), promotion of primary care, etc.

- Rationalisation of the Drug Tariff Standard.

- - Strengthened monitoring of doctor fee claim forms sent to insurers by medical care organs; i.e., increased monitoring staff and the introduction of national level monitoring of large claims.

- Enhanced guidance and supervision of medical care facilities by mobilising specialised doctors (establishment of an advisory body) and strengthening control over medical facilities (including cancellation of insurance medical care facility designation), thus eliminating overmedication and dishonest claims.

b) Partial cost-sharing at fixed rates by individuals covered by Employee Health Insurance

- The most important point in the present institutional reform is the introduction of cost-sharing to be paid by the insured person under Employee Health Insurance. Before the reform, the insured was granted full benefit for medical care expenses, except for the first visit fee ( $¥ 800)$ and for hospitalisation charges ( $¥ 500$ per day for the first month only). Co-insurance has been adopted in the present reform for the following reasons.

- First, there was a need to eliminate the difference between the insured and the dependent under Employees Health Insurance (20 per cent payment for hospitalisation, 30 per cent for other treatment) and National Health Insurance (30 per cent in both cases), from the viewpoint of equal benefits among insurance schemes.

. Second, the reasonable benefit rate is around 80 per cent, considering that the insurance contribution should not be raised but maintained at the present level if possible, and taking into account the present average benefit rate. 
- Third, a fixed-rate co-insurance will engender cost-consciousness in the patient, who will be informed of the medical care cost on the spot, thus bringing about more effective use of medical care services. In contrast, cost consciousness tends to fade on both the patient's and the facility's side when expenditures are covered 100 per cent.

Fourth, 100 per cent benefit is problematic in that it causes an imbalance of contribution between healthy insured persons and those susceptible to disease.

- The benefit rate for employees was lowered to 90 per cent $(80$ per cent beginning the day following notification by the Minister of Health and Welfare, if approved by the Diet in 1986 or later) for the above reasons. This should serve as the first step in the medium- and long-term plan to achieve an 80 per cent benefit rate for the total health insurance system, at the earliest possible date in the first half of the $1990 \mathrm{~s}$.

- At the same time, measures have been taken to relieve individuals and households affected by costly medical care by implementation of limits on total patient out-of-pocket costs. These include:

Provision of Benefits for Costly Medical Care when payment by the household exceeds $¥ 51000$ per month (in the previous system only expenditures by the individual were considered).

Further abatement for the patient who (a) receives the Benefit for High-Cost Medical Care numerous times, and/or (b) suffers from diseases requiring costly medical treatment for a long period (e.g. haemophilia, renal insufficiency requiring dialysis).

c) Creation of the retiree health insurance system

To rectify the irrational benefits and unfair contributions that existed in regard to aged retirees covered by the National Health Insurance, the Retiree Health Insurance System has been created:

Subjects: Retirees covered by the National Health Insurance (entitled to old-age pension) and dependents;

Benefits: Retiree $=80$ per cent as outpatient or inpatient Dependent $=80$ per cent as inpatient, 70 per cent as outpatient:

Eunding: National Health Insurance contributions from retiree and dependents and contributions from Employee Health Insurance.

The national subsidy for National Health Insurance has been reviewed, in considering that the creation of this Retiree Health Insurance System might affect National Health Insurance finances. 


\section{d) Creation of the Specific Medical Care Benefit}

With the diversification of values and the development of medical technology, the need for medical services has also become increasingly diversified and sophisticated. The Specific Medical Care Benefit has been created so as to harmonise medical care insurance with this new tendency.

Under the conventional health insurance system, whenever advanced technology not covered by health insurance was applied, the total examination or treatment would be considered ineligible for insurance coverage. Under the new system, if the patient receives certain high-technology medical care in specially approved medical care facilities (university hospital, etc.), the basic part of the medical costs which correspond to the conventional medical acts (i.e., basic examination and treatment) are provided as the Specific Medical Care Benefit. Differential payments, made when the inpatient's bed charge exceeds that covered by the insurance, have also been regularised and can now be covered by the Specific Medical Care Benefit.

\section{FUTURE POLICIES}

\section{More Rational and Effective Medical Care Expenditure}

Medical care expenditure must be rationalised and made more effective, from the aspects of both demand and supply, through comprehensive approaches such as disease prevention, improvement of the medical service system and appropriate management of the health insurance system. To this end, the following measures will be continued:

- upgrading of health activities, keeping track of the entire life cycle (medical check-ups, health guidance, etc.);

- improvement and rationalisation of the medical service system by systematisation of regional medical care, shared use of expensive medical equipment, review of medical staff education, etc.;

- rationalisation of the doctors' fees and the Drug Tariff Standard;

- reinforcement of the doctors' fee claim or investigation system; enhanced supervision and guidance of medical institutions.

\section{Unified Health Insurance System}

At present, health insurance in Japan is handled under several different schemes. To eliminate imbalances, system unification measures will be introduced from 1990 to 1995, with benefits standardised at roughly 80 per cent, and financial resources equalised by financial redistribution and other means. 


\section{COMPREHENSIVE HEALTH PROMOTION}

Degenerative diseases are expected to account for an increasing portion of Japan's total disease incidence. Whatever the changes, however, individual voluntary daily health control will remain the key to disease prevention and health promotion.

Therefore, national health consciousness must be enhanced, while at the same time a system must be established for providing effective health care services to satisfy the diverse health care demands of the full public spectrum. Concrete measures for comprehensive health promotion will include:

\section{Further encouragement of the National Health Promotion Movement}

The National Health Promotion Movement, initiated in 1978, will be stimulated by disseminating and enhancing public health consciousness and sanitation-mindedness as well as by taking health promotion and disease prevention measures throughout the life cycle in the community and the workplace.

- Health care services will be further improved by such means as arranging medical check-ups and health guidance for every phase of the life cycle.

- Community Health Centres will be constructed and upgraded to serve as the nucleus of community-wide health promotion. At the same time, functions of existing health centres as well as health manpower, including health nurses, will be systematically reinforced.

- Making full use of data processing systems, a network will be created between communities, health centres and medical institutions, thereby consolidating organic links between health and welfare services.

\section{Systematic Degenerative-Disease Countermeasures through Health Activities for the Aged}

Prevention of degenerative diseases, expected to continue to increase, essentially rests upon long-term health control, initiation of health promotion and periodic medical check-ups at middle age. To this end, health activities focusing on prevention of degenerative diseases wili be systematically implemented in conformance with the Law of Health and Medical Services for the Aged.

Other measures will include publicising the experience achieved in model communities, preparation of health maps and development of regional health activity plans by local governments. 
Cancer Countermeasures via the Comprehensive 10-year Strategy for Cancer Contro1

Deaths from cancer have increased year after year. Currently one in four Japanese deaths is attributable to this disease, and cancer control has become a concern of the entire nation.

In recent years, following the identification of oncogenes, the carcinogenic mechanism has gradually been unveiled. Some experts say that all-out cancer research now, with leading experts the world over working in unison, would control cancer this century.

Considering the current stage of cancer research, then-Prime Minister Yasuhiro Nakasone commissioned the Ministry of Health and Welfare to work out the comprehensive 10-year Strategy for cancer control. The Strategy, developed by the Specialist Council for Cancer Countermeasures (consisting of 10 cancer specialists), provided under the Cabinet Council for Cancer Countermeasures (organised in March 1983, with members of the Ministry of Health and Welfare and 4 other ministers), was approved by the Cabinet Council in June 1983.

The comprehensive 10-year Strategy, aimed at elucidating the essential nature of cancer in the coming decade, identifies six priority research subjects, including human oncogenes. The Strategy also involves the strengthening of international cooperation, the education and utilisation of young researchers, and the systematisation of a stable supply of high quality research material.

\section{Implementation of Mental Health Measures}

Given the recent increasingly complex social environment, neurosis, melancholia, psychosomatic diseases and other mental disorders have come to pose a serious problem.

To maintain and promote public mental health, Mental Health Centres in all prefectures will provide special offices where psychiatrists, psychologists and psychiatric social workers will give counselling and guidance in mental health. For those who suffer from mental disorders, day-care facilities will be increased to assist in their return to society.

In addition, to counter the expected increase in senile dementia concomitant with the ageing population, research into this disease will be promoted, while home visit services will be enhanced for more relevant consultation and guidance regarding the mental health of the elderly. 


\section{TOWARD IMPROVED MEDICAL SERVICES}

\section{Implementation of Regional Medical Care Plans}

\section{a) Tasks concerning the medical care system}

- Correction of regional imbalance

Although the Japanese medical service system as a whole, viewed from the quantitative aspect, has made important advances, considerable regional imbalance remains in the numbers of doctors and beds. Whereas some regions are oversupplied, remote mountain regions and regions with a rapidly expanding population are severely lacking in medical care facilities. Establishment of a nationwide well-balanced medical service system is thus a future task of crucial importance.

\section{- Functional networks among medical care facilities}

A current problem concerning Japanese medical care facilities is the independence of hospitals and clinics: mutual organic ties are insufficient. as is the development of networks of medical functions from primary care to advanced special treatment. With the recent advances in medical technology. patients increasingly choose well-equipped hospitals, as evidenced by the fact that since the mid-1970s, the number of outpatients has been decreasing in general clinics, while increasing in hospitals. Large hospitals in particular are crowded with patients, resulting in long delays and forcing such hospitals to expend such efforts in handling general patients that they sometimes cannot fulfil their advanced medical functions. This problem stems from unclear functional sharing among medical care facilities and the resultant lack in functional ties between them.

\section{b) Systematic streamlining of medical care system}

- Future policy

Fulfilment of the above tasks entails overall improvement of regional medical services. First, the medical care system must be streamlined in accordance with carefully devised plans. To develop a medical care system suited to a region's actual conditions and diverse medical care needs. a patchwork of measures is insufficient; comprehensive, well-coordinated approaches must be implemented over the entire medical care system. Second. medical care resource imbalances must be corrected to achieve appropriate and efficient distribution. To ensure equal medical care at anytime and at anyplace, medical care services must be strengthened, particularly in remote areas and for emergencies. Effort must also be exerted towards offering special medical care for cancer and other intractable diseases. In order to meet growing medical care demand within the limits of medical care resources. it is also necessary to consider how to most efficiently allocate medical care facilities, and the resultant lack in functional ties between them.

Third, well-defined function and role sharing must be realised anong the various medical care facilities, from clinics to advanced specialised hospitals. An approach to this end is the comprehensive and consistent enhancement of health and medical care services, ranging from health promotion 
to disease prevention, early detection, treatment and rehabilitation. Priority must be placed on primary care. Another approach is to "open" hospitals in various ways - including the construction of so-called "open-system" hospitals (utilised primarily by doctors not attached to a hospital) and Regional Centres for Continuing Medical Education as well as shared use of hospital medical equipment.

\section{- Regional medical care plans}

An effective means of establishing an appropriate regional medical care system is to work out medical care plans adapted to a region's actual conditions first and subsequently improve public and private medical care facilities in accordance with needs. The Ministry of Health and Welfare is systematically upgrading medical care functions, while advancing the networks between medical care facilities. With the aims of controlling unnecessary increases in the number of beds in already oversupplied regions and of systematising regional medical care, the Ministry introduced a Medical Service Law amendment bill into the Diet in 1983, proposing that a regional medical care plan include zoning for medical care while setting forth the number of beds required in each zone. The plan also provides for hospital functional improvement targets and steps to construct a functional and operational network between hospitals and clinics and the securing of the necessary medical staff.

\section{Study on Family Physicians}

With the increased specialisation of medicine and medical care, the subject of medical practice is tending to change from human beings to diseases and to organs. Most young doctors want to work at hospitals, a tendency which has resulted in the ageing of private practitioners, who play the central role in primary care. In addition, time spent for health counselling, diagnosis and treatment of each patient tends to be rather insufficient. And the trend is for patients to prefer large hospitals.

Responding to such trends while keeping as an objective the realisation of the ideal medical care structure based on a close doctor-patient relationship, experts are now deliberating as to the role of the family doctor (in charge of primary care), who is considered to play the central role in medical care continuation in that he provides daily health care, counselling, examination and treatment for minor sicknesses and injuries, introduces patients to specialised medical institutions when necessary, and offers other services people need in daily life.

\section{Intermediate Medical Facility}

For the elderly, among whom diseases are prevalent and many of whom suffer from hypertension and related conditions, sufficient dietary and exercise instruction, and other everyday points of contact are more important than ample treatment with medication and injections. 
As the greying of society proceeds, diversified needs of the aged. especially those requiring constant care, must be fulfilled. To achieve this, health and medical care facilities and welfare facilities must be closely

coordinated, implementing a comprehensive health and medical care policy. To this end, deliberations are now underway on the improvement of facilities for the elderly who do not have to be hospitalised and yet need sufficient care such as supervision and nursing. Also under consideration are facilities which function as mediator between facility and home and between welfare and medical care facilities by providing rehabilitation and training opportunities.

\section{Training of Medical Care Personnel}

In 1970 (at that time, there were 127 people engaged in medical care service for every 100 thousand people), the goal was to increase the number of doctors to at least the level of 150 doctors for every 100 thousand people. Toward this end, the plan to furnish a medical school in every prefecture was realised, promoting the training of future doctors. In 1983, the number of doctors totalled approximately 180000 , or 152 doctors for every 100000 people. Assuming this rise in numbers continues, it is estimated that there will be 220 doctors for every 100000 by the year 2000 and 300 doctors in 2025. As for dentists, the training of future dentists has been conducted with the aim of securing 50 dentists per 100000 people. In 1983, the number of dentists reached 66000,55 for every 100000 people. If this rate of training continues, the number is expected to increase to 83 dentists per 100000 by the year 2000 .

In view of these trends, future medical service demand prospects, and the regions' actual medical care conditions, the appropriate total number of doctors and dentists must be determined to prevent oversupply. This process is currently being carried out by the Future Doctor Supply/Demand and Future Dentist Supply/Demand Study Committees. An interim report on the number of doctors was submitted in November, 1984, proposing that:

1) Annual increases in the number of doctors be reduced at least 10 per cent by 1995, as a temporary target;

2) The doctor supply plans be continuously reviewed in response to circumstantial changes, so as to ensure that the government's medical service policy contributes directly to public well-being:

3) Parallel measures to be taken include establishment of role-sharing among doctors (family physicians, specialists, etc.), securing of the doctors necessary for remote area and emergency medical services, promotion of medical research, reinforcement of the public health field, strengthening of the management foundations of private medical colleges and upgrading of college and subsequent education.

An interim report on the number of dentists, submitted in December. 1984, proposes that:

1) Considering the time necessary for trimming the number of dentists, the annual increase in the number of dentists must be decreased by at least 20 per cent by 1995 , as a temporary target; 
2) The dentist supply plan be continuously reviewed in response to circumstantial changes, so as to keep dental care policy appropriate:

3) Parallel measures to be taken include improvement of remote area and emergency dental services, encouragement of dental health activities, securement of dental care for the physically or mentally handicapped and bedridden elderly people, upgrading of dental education, and promotion of dental research, development and lifelong education.

As regards doctor supply, well distribution among regions and medical fields is of as much importance as training and securing an appropriate number of doctors. The number of doctors per 100000 population in Japan in 1982 was 214 in the 11 major cities, 141 in other cities and 80 in towns and villages, reflecting continued doctor concentration in city areas. When viewed by field, there is a doctor shortage in public health. Rectifying this imbalance in the distribution of doctors among regions and fields is a vital task for the future.

Regional imbalance prevails among nurses and similar medical staff. Measures to secure 662800 nurses, etc. were underway in 1985 . Efforts must also be devoted to train high quality nurses to keep up with medical care advances and changing medical care demand trends. 
Part 2

PENSION REEORM IN JAPAN

\author{
INTRODUCTION
}

Income security in old age may be achieved through public pensions, occupational pensions, individual pensions and income from employment. of these, the public pension system is a social support system whereby compulsory contributions are levied on the whole population and benefits are provided in old age and for other circumstances requiring pension protection. It is. moreover, an income security system whereby real income is maintained even though there are changes in prices and living standards.

The public pension system is the nucleus of income security in old age and shoulders the fundamental burden of that security. People place great trust in it and expect a lot of it. It is therefore of utmost importance that the system be stable over the long term, even during periods of severe social and economic change.

Though the public pension system acts as the nucleus of security for the elderly, it provides for their basic needs. Additional needs are provided for by occupational pensions, individual pensions and other schemes.

The basis of the public pension system is social solidarity. Consideration also has to be given to the balance between the level of pensions received by the elderly generation and the living standards and liabilities of the working generation supporting the system (equity between the generations).

Moreover, there are discrepancies with respect to benefit contents and conditions for those belonging to the same generation, depending on the pension system to which they have subscribed. Inequalities in benefits and liabilities threaten social solidarity, and must be avoided (equity within generations).

Reforms have begun in Japan to establish a durable public pension system for the future. They include reforms of the Employees Pension Insurance and National Pension, the two major public pension schemes. The Ministry of Health and Welfare began examining reforms in 1981 . In March 1984 an reform bill was submitted to the Diet and was approved and enacted on 24th April 1985 for implementation as of April 1986. The details of the reform are discussed below. Briefly, the chief elements of the reforms are the reorganisation of the system with the introduction of the basic benefit. 
the rationalisation of benefit levels and through this a restraint on increases in future liabilities, the establishment of women's rights to benefits on an individual basis, and the improvement of pension security for the disabled.

In addition, reform of the various mutual aid pension schemes for public service personnel and other employees in specific industries is under preparation. A reform bill is now being deliberated upon in the Diet with a view to realising reforms similar to those for Employees' Pension Insurance and National Pension at the same time, April 1986.

The objective is to completely reform Japan's public pension system so that it may enter a new era from April 1986.

\section{PRESENT SITUATION OF PUBLIC PENSION SYSTEM AND PROBLEMS}

\section{PRESENT SITUATION OF PUBLIC PENSION SYSTEM}

\section{History and Organisation of Japan's Public Pension System}

The first step in developing Japan's pension system was the introduction of annuity schemes for certain government employees in the military and civil services. Later, the Workers Pension Insurance was inaugurated in 1942 to provide coverage for male manual workers employed in factories and mines. In 1944 coverage was extended to office employees and female workers and the name of the scheme was changed to Kosei Nenkin Hoken or Employees' Pension Insurance (hereinafter referred to as the "employees' scheme" or EPI). This scheme underwent a full-scale reconstruction in 1954, thus creating the original form of the existing EPI. 1

At that time certain occupational groups seceded from EPI to estabish pension schemes by means of independent associations (Mutual Aid Associations or MAAs). Thus in 1954 and again in 1959 private school teachers and employees of agricultural, forestry and fishery cooperatives formed their own mutual aid association schemes. Annuity systems for central government and local government civil servants were also converted to National Public Service Employees and Local Public Service Employees mutual aid associations.

Nationwide pension coverage was realised in 1962 when the National Pension Scheme (hereinafter referred to as the National Scheme or NPS) was established for those not covered by the employee pension schemes -. for example, the self-employed, those engaged in agriculture, forestry and fisheries and spouses of those not classified as employees. ${ }^{2}$

Hence, Japan's public pension scheme originated from annuity and EPI schemes. Thereafter it underwent a number of amendments before taking on its present form whereby there is a separation according to occupation in which EPI covers general employees, the four mutual aid association schemes cover public service personnel and NPS covers the self-employed, farmers and others. ${ }^{3}$ 
Even though Japan's pension schemes are separated according to occupation, they each provide insurance coverage for old age, disability and death and the pension benefit levels are based on contributions. They therefore operate as a form of social insurance. In the case of the employees' and MAA schemes, the insured person pays a predetermined ratio of his or her wages as a contribution, and the pension benefit calculations are based on the insured period and wage history. ${ }^{4}$ Upper and lower limits have been set for the wages (insured remuneration) which constitute the basis for calculating the premiums and benefits for employees' pension (see Table 5).

In the case of the national scheme, the contribution levied is a fixed amount and the benefits are calculated proportionate to the number of months of contributions which have been made.

\section{Present Situation of Each Public Pension Scheme}

The numbers of those making contributions to each of Japan's pub1ic pension schemes and of those eligible for benefits are shown in Table 4 . The total number of subscribers to the public pension schemes is about 58 million ( 48 per cent of the total population) and the total number of eligible beneficiaries amounts to 19 million (16 per cent of the population). The employees' and national schemes together account for some 90 per cent of both subscribers and beneficiaries, thereby forming the foundation of the country's public pension system.

Reference to the ratio of those eligible for old age pension to the insured for each scheme suggests that, as a whole, the ratio for Japan's public pension system is low and that the system is immature. However, a closer look reveals that there are some schemes with high ratios of eligible beneficiaries and that they are progressing towards maturity.

\section{Financial Resources of Public Pension System}

Japan's public pension benefits are financed by means of contributions imposed on the insured persons and employers plus state subsidies (Table 5). Generally speaking, the schemes are immature and overall the premium levels are lower than those in other OECD countries. But in some cases, reflecting the increase in the ratios of eligible beneficiaries mentioned above, the burden is becoming considerable. Moreover, as is detailed in the Annex below, the cumulative reserves for the employees' scheme and the national scheme amounted to around $¥ 48000 \quad 000$ million (estimate) as of the end of fiscal 1984. Of this, the reserves accumulated by the employees' scheme were $¥ 45000000$, or 6.3 times annual benefit costs, and those accumulated by the national scheme are $¥ 2900000$, or 1.0 times annual benefit costs.

At present these reserves are deposited with the Trust Fund Bureau of the Ministry of Finance and are utilised as a source or investment for improving housing, the living environment and other aspects of social support. In addition, every year a fixed amount of the increase in reserves is applied directly as refinance loans to contributors for improving the livelihood of the insured persons and their dependents. 
Table 4

Outline of public pension schemes - as of JUNE $1985^{a}$

\begin{tabular}{|c|c|c|c|c|c|c|}
\hline Scheme & Insured Persons & 'Insuirer & $\begin{array}{c}\text { Number of } \\
\text { contributors } \\
\text { (1 } 000 \text { persons) }\end{array}$ & $\begin{array}{c}\text { Number of } \\
\text { beineticiaries } \\
\text { (1 000 persons) }\end{array}$ & $\begin{array}{l}\text { Number of } \\
\text { Old-Age Pension } \\
\text { Beneficiaries } \\
\text { (1 000 persons) }\end{array}$ & $\begin{array}{l}\text { Ratio of } \\
\text { Old-Age Pension } \\
\text { Beneficiaries }\end{array}$ \\
\hline $\begin{array}{l}\text { Employees' Pension } \\
\text { Insurance }\end{array}$ & $\begin{array}{l}\text { Private Sector } \\
\text { Salaricd Workers }\end{array}$ & State & 26360 & 6140 & 2730 & 10.4 \\
\hline Seamen's Insurance & Seafarers & State & 190 & 110 & 60 & 31.4 \\
\hline $\begin{array}{c}\text { National } \\
\ddots\end{array}$ & $\begin{array}{l}\text { Employees of Central } \\
\text { Government }\end{array}$ & $\begin{array}{l}\text { The Federation of } \\
\text { National Public } \\
\text { Service MAAs. }\end{array}$ & 1170 & 450 & 340 & 29.4 \\
\hline Public Service & $\begin{array}{l}\text { Employees of Japan } \\
\text { National Railways }\end{array}$ & $\begin{array}{l}\text { National Railways } \\
\text { MAA }\end{array}$ & 360 & 370 & 270 & 77.2 \\
\hline \multirow[t]{2}{*}{ MAAs } & $\begin{array}{l}\text { Employees of Nippon } \\
\text { Telephone \& } \\
\text { Telegraph Co. Ltd. }\end{array}$ & $\begin{array}{l}\text { Telephone \& } \\
\text { Telegraph MAA }\end{array}$ & 320 & 80 & 60 & 19.5 \\
\hline & $\begin{array}{l}\text { Employees of Japan } \\
\text { Tobacco Co. Ltd. }\end{array}$ & $\begin{array}{l}\text { Tobacco } \\
\text { Industry MAA }\end{array}$ & 40 & 20 & 20 & 52.8 \\
\hline $\begin{array}{l}\text { Locil Public } \\
\text { Service MAAs }\end{array}$ & $\begin{array}{l}\text { Employees of } \\
\text { local government }\end{array}$ & $\begin{array}{l}\text { The Federation of } \\
\text { Local Public Service }\end{array}$ & 330 & 940 & 720 & 22.0 \\
\hline $\begin{array}{l}\text { Private School } \\
\text { Teachers \& Employees }\end{array}$ & $\begin{array}{l}\text { Private School } \\
\text { Teachers \& } \\
\text { Employees }\end{array}$ & $\begin{array}{l}\text { Private School } \\
\text { Teachers \& } \\
\text { Employees } \\
\text { MAA }\end{array}$ & 330 & 60 & 10 & 3.9 \\
\hline $\begin{array}{l}\text { Agricultural. Forestry } \\
\text { \& Fishery Cooperative } \\
\text { Employees' MAAs }\end{array}$ & $\begin{array}{l}\text { Employees of } \\
\text { Cooperatives } \\
\text { \& Allied Bodies in } \\
\text { Agriculture. Forestry } \\
\text { \& Fishery }\end{array}$ & $\begin{array}{l}\text { Agricultural, } \\
\text { Forestry \& Fishery } \\
\text { Co-operative } \\
\text { Employees' MAAs }\end{array}$ & 490 & 130 & 80 & 16.2 \\
\hline $\begin{array}{l}\text { National Pension } \\
\text { (Contributory System) }\end{array}$ & $\begin{array}{l}\text { Self employed, ctc. } \\
\text { (Spouses of employees } \\
\text { can be voluntary } \\
\text { contributors) }\end{array}$ & State & & & & \\
\hline $\begin{array}{l}\text { (Pension } \\
\text { Non-Contributive) }\end{array}$ & & & & 2970 & 2350 & \\
\hline Total & & & 58280 & 19120 & 12960 & 22.2 \\
\hline
\end{tabular}

Source: Japanese Ministry of Health and Welfare. 
Table 5

Contributions for public pension schemes as of June 1985

\begin{tabular}{|c|c|c|c|c|c|}
\hline \multirow{2}{*}{\multicolumn{2}{|c|}{ Scheme }} & \multirow{2}{*}{$\begin{array}{c}\text { Standard Remuneration \& } \\
\text { Maximum \& Minimum } \\
\text { Wages }\end{array}$} & \multicolumn{2}{|c|}{ Contribution Rate } & \multirow{2}{*}{ State Subsidy } \\
\hline & & & Employer & Insured Person & \\
\hline \multicolumn{2}{|c|}{$\begin{array}{l}\text { Employees' Pension } \\
\text { Insurance }\end{array}$} & $\begin{array}{l}45000 \text { Yen } \\
440000 \text { Yen } \\
\text { (From Oct. } 1985 \\
68000 \text { Yen } \\
470000 \text { Yen) }\end{array}$ & $\begin{array}{l}5.3 \% \text { (Women } 4.65 \% \\
\text { Miners } 5.9 \% \text { ) } \\
\text { (From October 1985: } 6.2 \% \\
\text { Women } 5.65 \% ; \text { Miners } 6.8 \% \text { ) }\end{array}$ & $\begin{array}{l}5.3 \% \text { (Women } 4.65 \% \\
\text { Miners 5.9\%) } \\
\text { (From October 1985: 6.2\%; } \\
\text { Women 5.65\%; Miners } 6.8 \% \text { ) }\end{array}$ & $\begin{array}{l}20 \% \text { of benefit costs } \\
\text { (25\% for miners) }\end{array}$ \\
\hline \multicolumn{2}{|c|}{ Seamen's Insurance } & $\begin{array}{l}45000 \text { Yen } \\
440000 \text { Yen } \\
\text { (Ditto) }\end{array}$ & $\begin{array}{l}6.25 \% \\
\text { (Ditto 6.8\%) }\end{array}$ & $\begin{array}{l}6.25 \% \\
\text { Ditto }(6.8 \%)\end{array}$ & $25 \%$ of benetit costs \\
\hline \multirow{2}{*}{$\begin{array}{l}\text { National } \\
\text { Public } \\
\text { Service } \\
\text { MAAs }\end{array}$} & Cent. Gov. & 450000 Yen max. & $7.65 \%[6.12 \%]^{a}$ & $7.65 \%[6.12 \%]^{a}$ & $15.85 \%$ of benefit costs \\
\hline & $\begin{array}{l}\text { J.N.R. } \\
\text { N.T.T. }\end{array}$ & $\begin{array}{l}450000 \text { Yen max. } \\
450000 \text { Yen max. }\end{array}$ & $\begin{array}{c}10.2 \% \\
7.13 \%[5.16 \%]^{a} \\
{[5.70 \%]^{a}}\end{array}$ & $\begin{array}{c}10.2 \% \quad[8.16 \%]^{a} \\
7.13 \%[5.70 \%]^{a}\end{array}$ & $\begin{array}{l}15.85 \% \text { of benefit costs } \\
\text { (National Railways } \\
\text { responsible for J.N.R. } \\
\text { bonds }\end{array}$ \\
\hline \multicolumn{2}{|c|}{$\begin{array}{l}\text { Jocal Public } \\
\text { Service MAAs }\end{array}$} & $\begin{array}{l}450000 \text { Yen max. } \\
450000 \text { Yen max. }\end{array}$ & $\begin{array}{l}8.68 \%[6.94 \%]^{a} \\
\text { General } 6.9 \%[5.52 \%]^{a}\end{array}$ & $\begin{array}{l}8.68 \%[6.94 \%]^{a} \\
6.9 \%[5.52 \%]^{a}\end{array}$ & $\begin{array}{l}15.85 \% \text { of all revenue } \\
\text { (Responsibility of local } \\
\text { public sector } \\
\text { organisations) }\end{array}$ \\
\hline \multicolumn{2}{|c|}{$\begin{array}{l}\text { Private School } \\
\text { Teachers \& }\end{array}$} & $\begin{array}{r}75000 \text { Yen } \\
450000 \text { Yen }\end{array}$ & $5.1 \%$ & $5.1 \%$ & $\begin{array}{l}18 \% \text { of all benefit costs } \\
\text { (also fixed amount } \\
\text { assistance) }\end{array}$ \\
\hline \multicolumn{6}{|c|}{ Employers MAAs } \\
\hline \multicolumn{2}{|c|}{$\begin{array}{l}\text { Agricultural, Forestry \& } \\
\text { Fishery Co-operative }\end{array}$} & $\begin{array}{r}75000 \text { Yen } \\
450000 \text { Yen }\end{array}$ & $5.45 \%$ & $5.45 \%$ & $\begin{array}{l}18 \% \text { of all benefit costs } \\
\text { (also fixed amount } \\
\text { assistance) }\end{array}$ \\
\hline \multicolumn{6}{|c|}{ Employees MAAs } \\
\hline \multicolumn{2}{|c|}{ National Pension } & - & - & 6740 Yen (fixed) & $1 / 3$ of benefit costs \\
\hline
\end{tabular}

Source: Japanese Ministry of Health and Welfare. 


\section{CHANGES IN SOCIO-ECONOMIC ENVIRONMENT}

A pension system is one aspect of the social framework and evolves against the background of the socio-economic conditions pertaining in the country in question. When there are changes in the social and economic circumstances, the system must adapt to accommodate them. From this standpoint, there are three main changes in Japan's situation which have a bearing on the pension system. These are: the ageing of the population, the advance of women in the labour market and other changes in the employment structure (urbanisation, more employed people).

\section{Ageing of Population Structure}

While the average life expectancy of the Japanese in 1945 was about 50 , it has grown considerable and is approaching 80 (Charts 3 and 4 ). Also, in recent years the birth rate has been low, and the prediction is that in the future there will be rapid ageing of the population structure.

According to population estimates (October 1984) by the Statistics Bureau of the Prime Minister's Office, those aged 65 and over account for 9.9 per cent of the total population (Chart 5). The Future Population Estimates (Ministry of Health and Welfare) published in November 1981, forecasts that the elderly population (aged 65 or over) will grow substantially so that by 2000 it will be 15 per cent and in the peak period around 2020 it will reach 21.8 per cent (Chart 6).

With this burden of ageing, the administration of the pension schemes in the first half of the 21 st century will be difficult. With this in mind it must be noted that under the present pension system there are discrepancies between the schemes. Moreover, there is concern that a trend could develop giving rise to exorbitant benefits and obligations and that the balance within and between the generations will be impaired.

\section{Changes in Employment Structure}

When Japan's public pension system was completed in 1955, the general employees accounted for 40 per cent of the total work force. The self-employed and farmers were the largest group, accounting for a little less than 60 per cent. With rapid industrialisation and urbanisation the number of general employees grew substantially so they now constitute over 70 per cent of all employed persons (Chart 7).

As a result of this change in the employment structure, the support mechanisms within the family (which were widespread during the era when the farmers and self-employed were large groups) have altered. In the industrialised society, where the number of large families has declined and the nuclear family is the norm, there is little scope for entrusting the care of the elderly to family members. Moreover, in contrast to farmers and the self-employed, when general employees retire they generally forfeit practically all of their sources of income. It is apparent that the increase in the number of general employees heightens the importance of the public pension system. 
Chart 3

TRENDS IN AVERAGE LIFE EXPECTANCY AT BIRTH
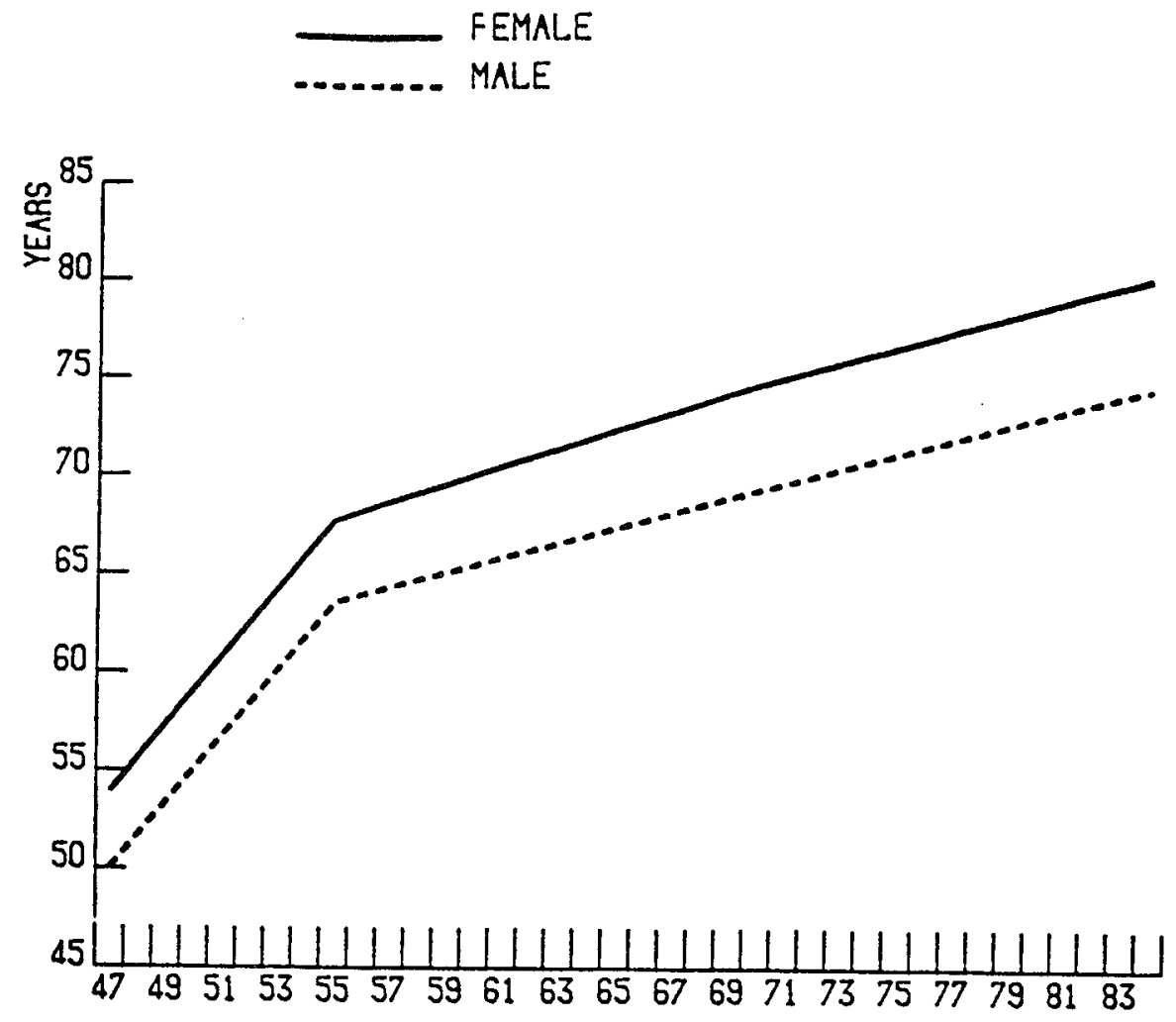

Chart 4

TRENDS IN AVERAGE LIFE EXPECTANCY AT BIRTH

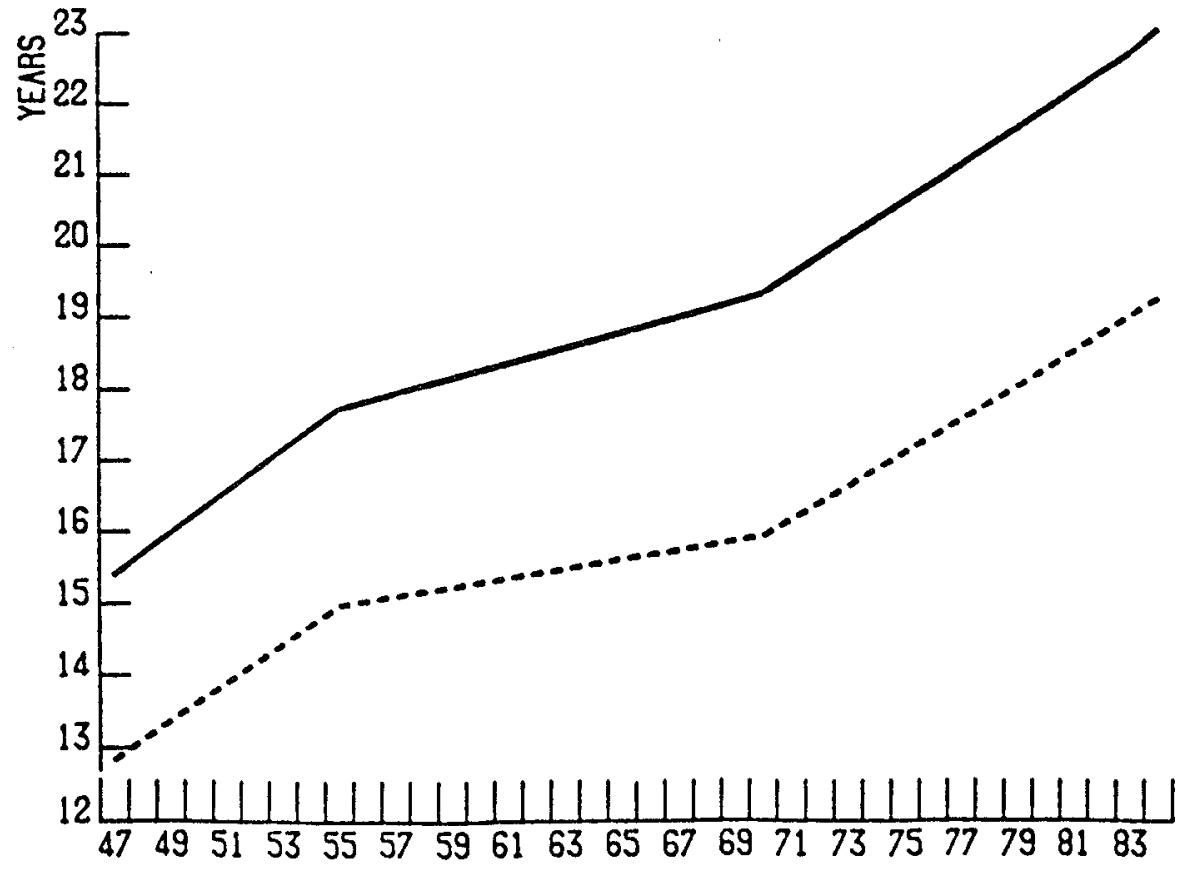

source: Japanese Ministry of Health and Welfare. 
Chart 5

POPULATION STRUCTURE

(As of 1st October 1984)

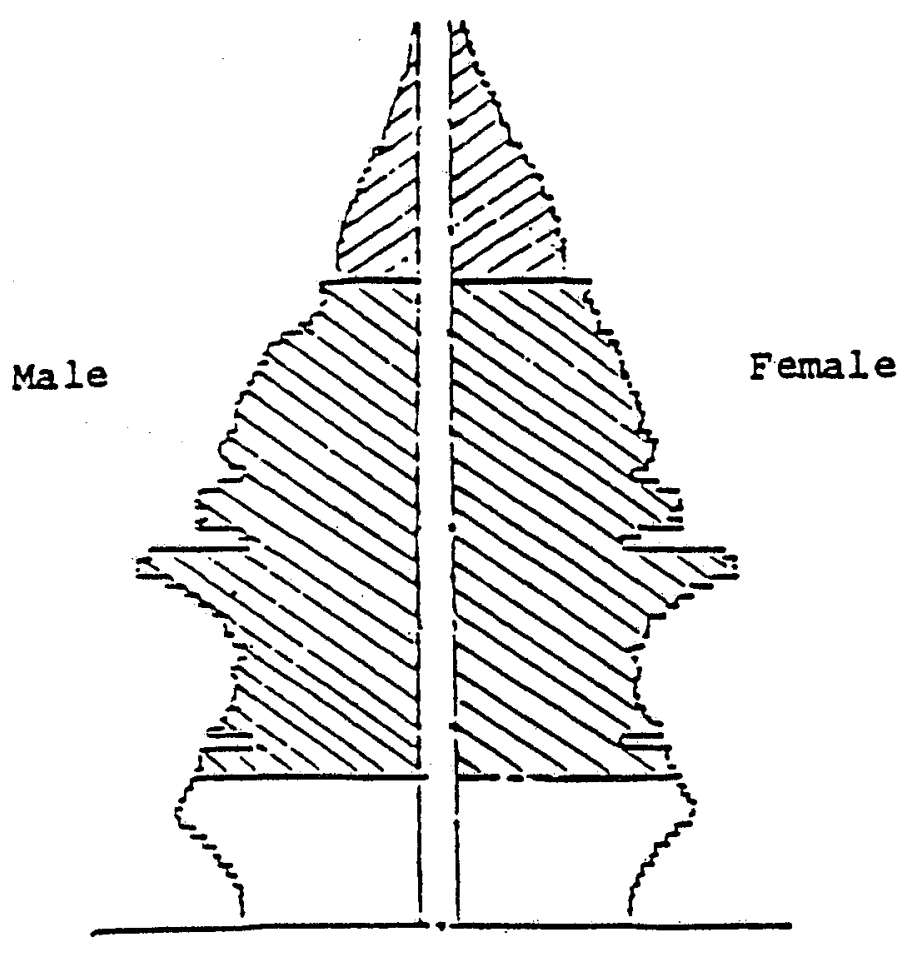

Chart 6

PROJECTED CHANGES IN POPULATION STRUCTURE

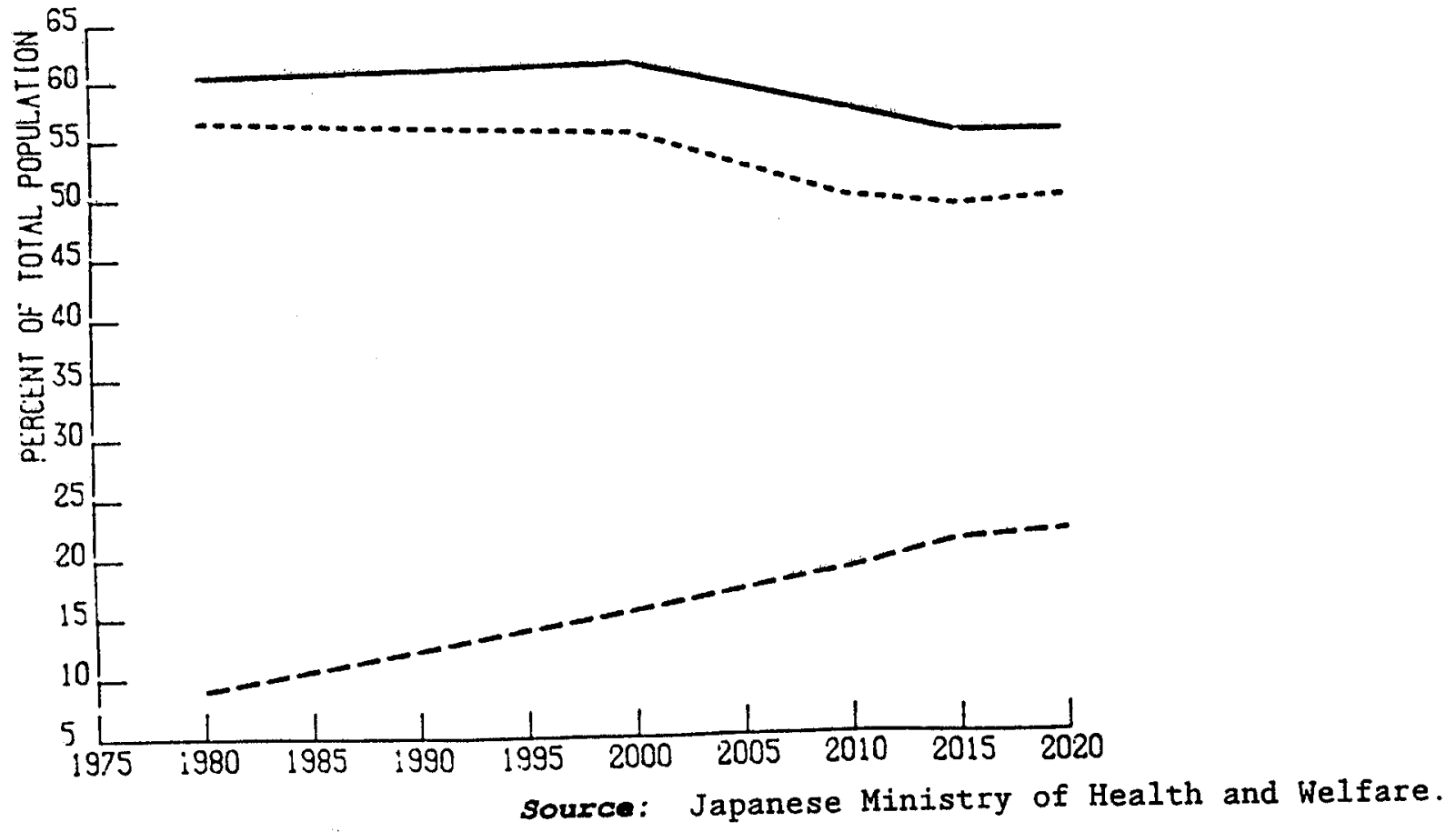


Chart 7

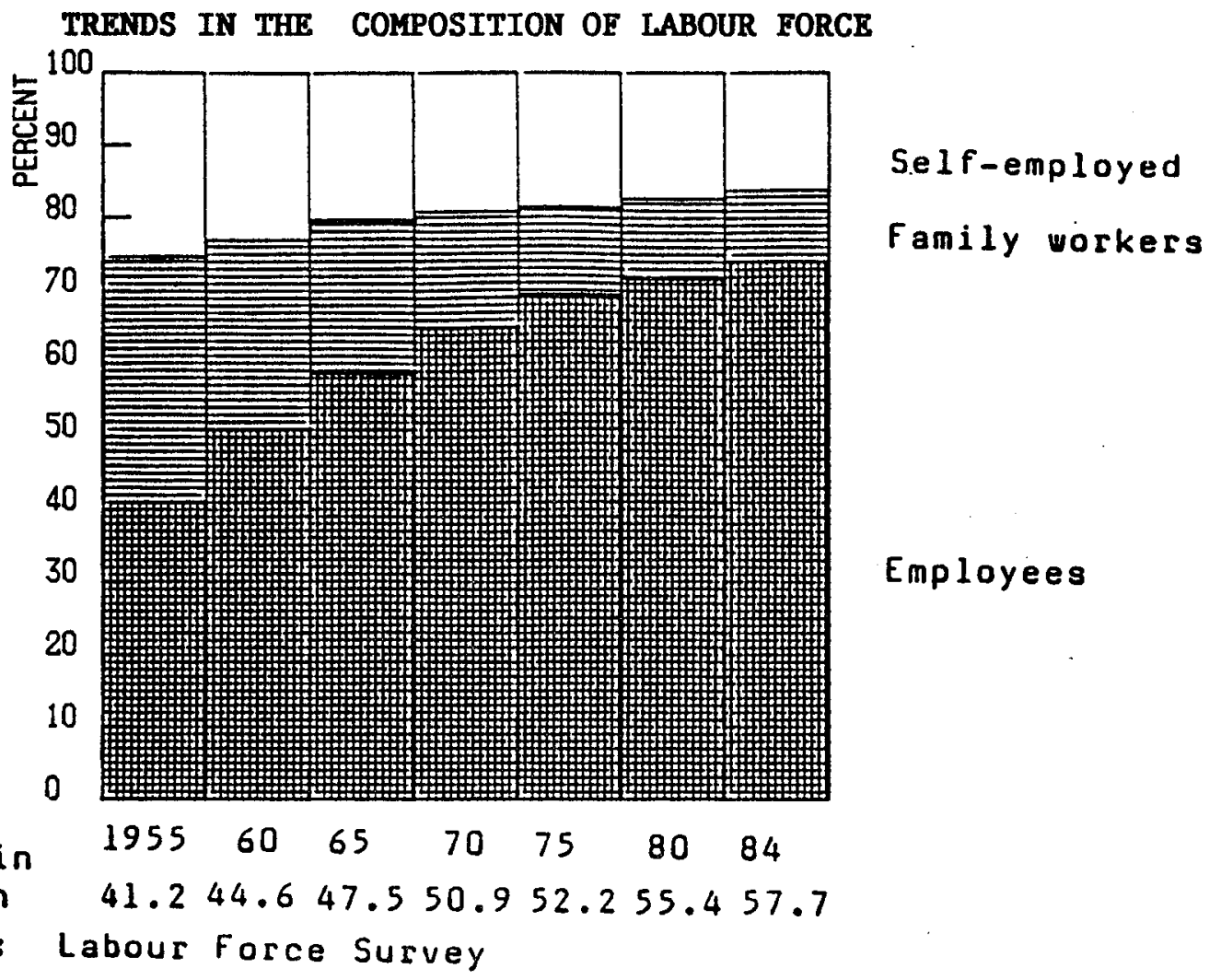

Chart 8

TRENDS IN THE ACTIVITY PATTERN OF WIVES

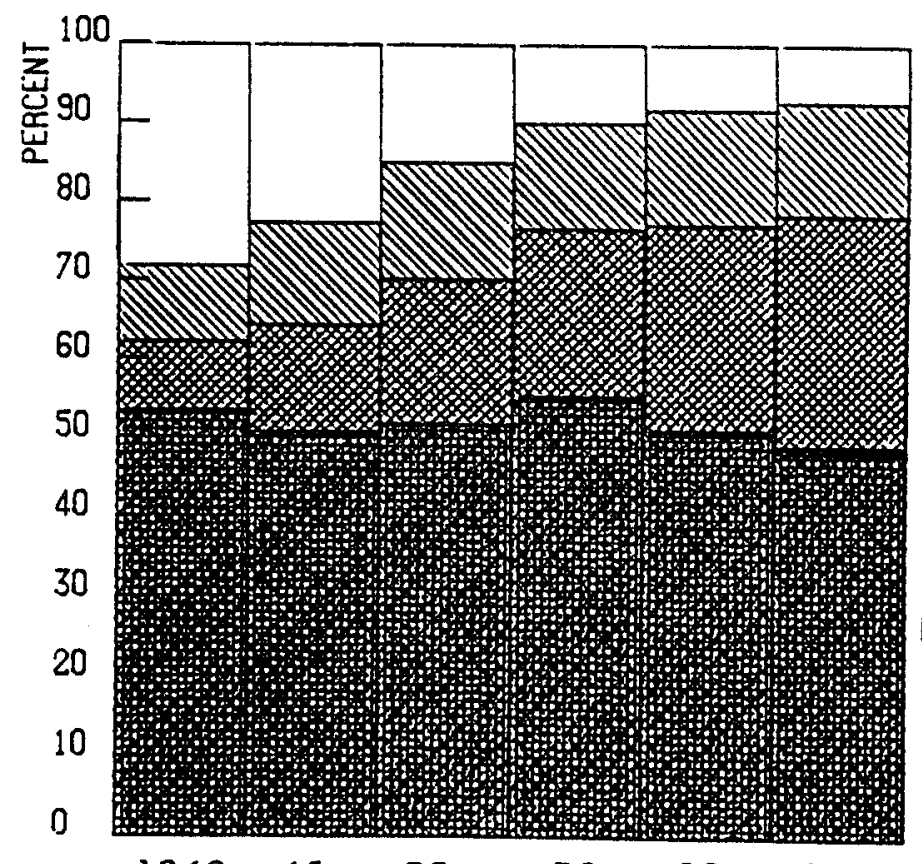

Agriculture \& Forestry

Self-employed

family workers

Employees

Non-active

Total in

million

$\begin{array}{llllll}1960 & 65 & 70 & 75 & 80 & 84\end{array}$

$\begin{array}{llllll}19.2 & 21.9 & 24.6 & 27.9 & 29.6 & 30.6\end{array}$

Source: Labour Force Survey 
With a pension system divided according to occupations there are a number of potential problems. Put simply, EPI is for general employees and NPS is for farmers and the self-employed, and as the proportion of general employees increases so the number of persons shouldering the burden of the contributions to EPI increases, thus making EPI financially sound. However, the proportion contributing to NPS decreases, and the point has now been reached when the validity of a system which segregates people on the basis of occupation must be questioned (see Section III).

\section{Increasing Employment of Women}

Over the past few decades female employment in Japan has undergone a transition. In particular, the form of employment for married women has changed remarkably. as can be seen in Chart 8 . Although, half of married women are still full-time housewives, from 1960 to 1983 married women employed increased dramatically from 1690000 to 8930000 (from 8.8 per cent to 29.2 per cent).

EPI and the MAA schemes were designed on the basis that benefits were for the household as a unit, to provide security in old age not only for the insured person but also for the spouse. However, with married women also working and subscribing to the employees pension schemes, it is now not unusual for these women to receive their own individual pensions. In households where both husband and wife work, employees' pension provides coverage for the spouse in either case and they both receive their respective benefits as insured persons. This type of benefit format, where the household is regarded as a unit. can lead to structurally excessive benefits. The system was reviewed with the idea of establishing women's rights to benefits on an individual basis (see Section III).

\section{PROBLEMS OF THE PUBLIC PENSION SYSTEM}

\section{Problems due to Fragmentary Structure}

Japan's public pension system has three components separated into seven schemes according to occupation. With this range of schemes the following problems have emerged: (a) discrepancies between schemes; (b) overlapping and excessive benefits; (c) instability of the financial base due to changes in employment structure.

\section{a) Discrepancies between schemes}

With seven separate public pension schemes, each with its own individual objectives and historical development, there have been differences in the benefit systems and conditions for provision (Table 6). For example, the age at which the provision of benefits commences is 60 for EPI, 65 for NPS and 56 for the MAAs (raised in stages to 60 by 2000). Again, the basic remuneration used for the calculation of pension benefits is the average wage during the contribution period for EPI and the average actual wage (excluding allowances) for the year prior to retirement for the MAA schemes. 
Table 6

Current differences between public pension schemes

\begin{tabular}{|c|c|c|c|c|c|}
\hline Item & & National Pension & $\begin{array}{l}\text { Employees' Pension } \\
\text { Insurance }\end{array}$ & $\begin{array}{l}\text { National Public Local } \\
\text { Public Service JNR } \\
\text { NTT \& JTC Employees }\end{array}$ & $\begin{array}{c}\text { Private School Teachers or } \\
\text { Employees of Agricultural } \\
\text { Forestry \& Fishery } \\
\text { Co-operatives }\end{array}$ \\
\hline 1: & $\begin{array}{l}\text { Benefit calculation } \\
\text { Method } \\
\text { (Annual amount) }\end{array}$ & $\begin{array}{l}\text { Y } 2000 \times \text { no. of } \\
\text { monthly contributions }+ \\
Y 2000 \times \text { no. of } \\
\text { insurance months } \times 1 / 3 \\
\times \text { Price adjustment ratea }\end{array}$ & $\begin{array}{l}\text { (Y } 2400 \times \text { no. of } \\
\text { monthly contributions }+ \\
10 / 1000 \times \text { monthly wage } \\
\text { base } \times \text { no. of } \\
\text { contribution months) } x \\
\text { Price adjustment rate }\end{array}$ & \multicolumn{2}{|c|}{$\begin{array}{l}\text { 1. }(40 / 100+1.5 / 100 \times \text { no. of contribution ycars in } \\
\text { excess of } 20 \text { years }) \times \text { monthly wage base } \\
\text { 2. Whichever is the highest for any of the EPI } \\
\text { schemes }\end{array}$} \\
\hline $2^{\circ}$ & $\begin{array}{l}\text { Wage base for benefit } \\
\text { calculation }\end{array}$ & - & $\begin{array}{l}\text { Average monthly wage } \\
\text { over whole contribution } \\
\text { period }\end{array}$ & $\begin{array}{l}\text { Average monthly wage } \\
\text { for the year prior to } \\
\text { retirement }\end{array}$ & $\begin{array}{l}\text { Choice of either average } \\
\text { monthly wage for the year } \\
\text { prior to retirement or for } \\
\text { the whole contribution } \\
\text { period whichever is higher }\end{array}$ \\
\hline 3. & $\begin{array}{l}\text { Scope of wages and } \\
\text { remuneration assessed }\end{array}$ & - & $\begin{array}{l}\text { All labour-related } \\
\text { remunerations except } \\
\text { bonuses }\end{array}$ & $\begin{array}{l}\text { Actual wage } \\
\text { (excluding bonuses and } \\
\text { other allowances) }\end{array}$ & Same as EPI \\
\hline 4. & Pensionable age & \multicolumn{4}{|c|}{ Both male and female 65 Male 60 . Female, 55 (being gradually raised for female to 60 by the year 2000) } \\
\hline s. & $\begin{array}{l}\text { Adjustments for own } \\
\text { and survivors pension }\end{array}$ & \multicolumn{2}{|c|}{$\begin{array}{l}\text { Under the same scheme, in principal, one of the } \\
\text { pensions must be selected }\end{array}$} & \multicolumn{2}{|c|}{$\begin{array}{l}\text { Even if in the same scheme, survivors' pension is } \\
\text { provided together with old-age or disability pension }\end{array}$} \\
\hline & $\begin{array}{l}\text { (Prix en } 1984=100) . \\
\text { CNJ = Chemins de fer nat } \\
\text { NTT = Nippon Telephone }\end{array}$ & $\begin{array}{l}\text { tionaux japonais. } \\
\text { \& Telegraph. }\end{array}$ & & & \\
\hline
\end{tabular}

Source: Japanese Ministry of Health and Welfare. 


\section{b) Qverlapping and excessive benefits}

Because the schemes are separate and each has its own benefit plans, there are cases where individuals are receiving benefits from more than one scheme. At times they are receiving excessive benefits in terms of the social
security system.

For example, when a husband who has been a public service employee dies, his wife is provided with a survivor's pension from the mutual aid association in question. If she herself is contributing to EPI, she can also receive a full old age pension from that scheme in addition to the survivor's benefit, with no adjustments made. (If the husband is also a subscriber to EPI, an adjustment is made). In Japan there is generally a fixed retirement age of 55-60 years for salaried workers. Should a public service employee take another job with a company in the private sector after old-age retirement, he is still provided with his total pension as a retired public servant even if he is receiving a fairly substantial salary from his new employer. However. when a person employed by a company in the private sector retires on reaching the prescribed age limit and is thereafter employed by another private company, he is not entitled to his pension because he has moved from one company to another, both within the employees' scheme.

\section{c) Instability of the financial base due to changes in employment}

As stated in Section II, because of labour force transfers between occupations caused by changes in the industrial structure, there have been marked changes to the financial base of each scheme. The pension schemes are such it to cope with contributions and benefits over the long term and as With separate schemes, the insurance groups also have long-term stability. changes in the shifts between occupations. unstable.

\section{Structurally High Benefit Levels and Contribution Rates}

Historically, Japan has an immature pension system. In the longer term, when the system matures there will be a problem with benefit levels. At present the EPI has an average contribution period of 32 years for new male beneficiaries. With maturation of the system, this average contribution period will be extended and it is predicted that 40 years will finally become the norm. As the contribution period lengthens, the pension benefit grows, and if the system remains as it is, future benefit levels will be high
compared with the wages of the actively employed.

For EPI, with 32 years contributions, the benefit level is 68 per cent of the average wage of those actively employed. 5 With a 40 -year contribution period, if the system remains unchanged the benefit level will reach 83 per cent. When the wife has been an optional subscriber to NPS for a period of 40 years. the total pensions received by husband and wife is 109 per cent of insurance premiums (chart 9). In order to support this high benefit level, between the employer and have to be 38.8 per cent of wages (shared equally bonuses are included). 
Chart 9

REPLACEMENT RATES AND PENSION RMOUNT

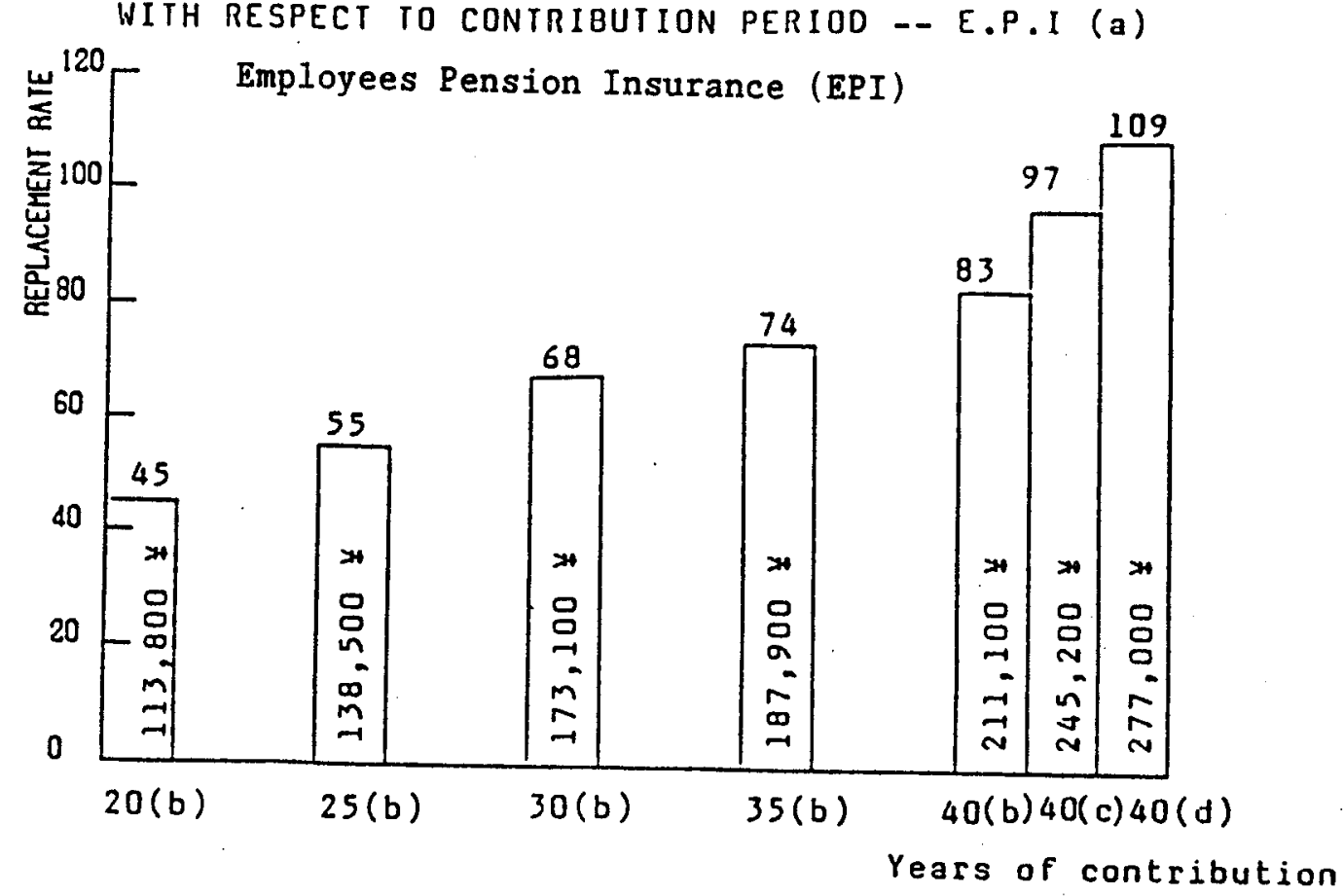

Notes: a) Average wage of $¥ 254,000=100$

b) Including spouse supplement of $¥ 15,000$

c) 25 years of contribution to N.P. by wife

d) 40 years of contribution to N.P. by wife.

Source for both Chart 9 and 10: Japanese Ministry of Health and Welfare.

Chart 10

BENEFIT STRUCTURE AND BENEFIT LEVELS FOR DIFFERENT TYPES OF HOUSEHOLDS - - EPI (a)
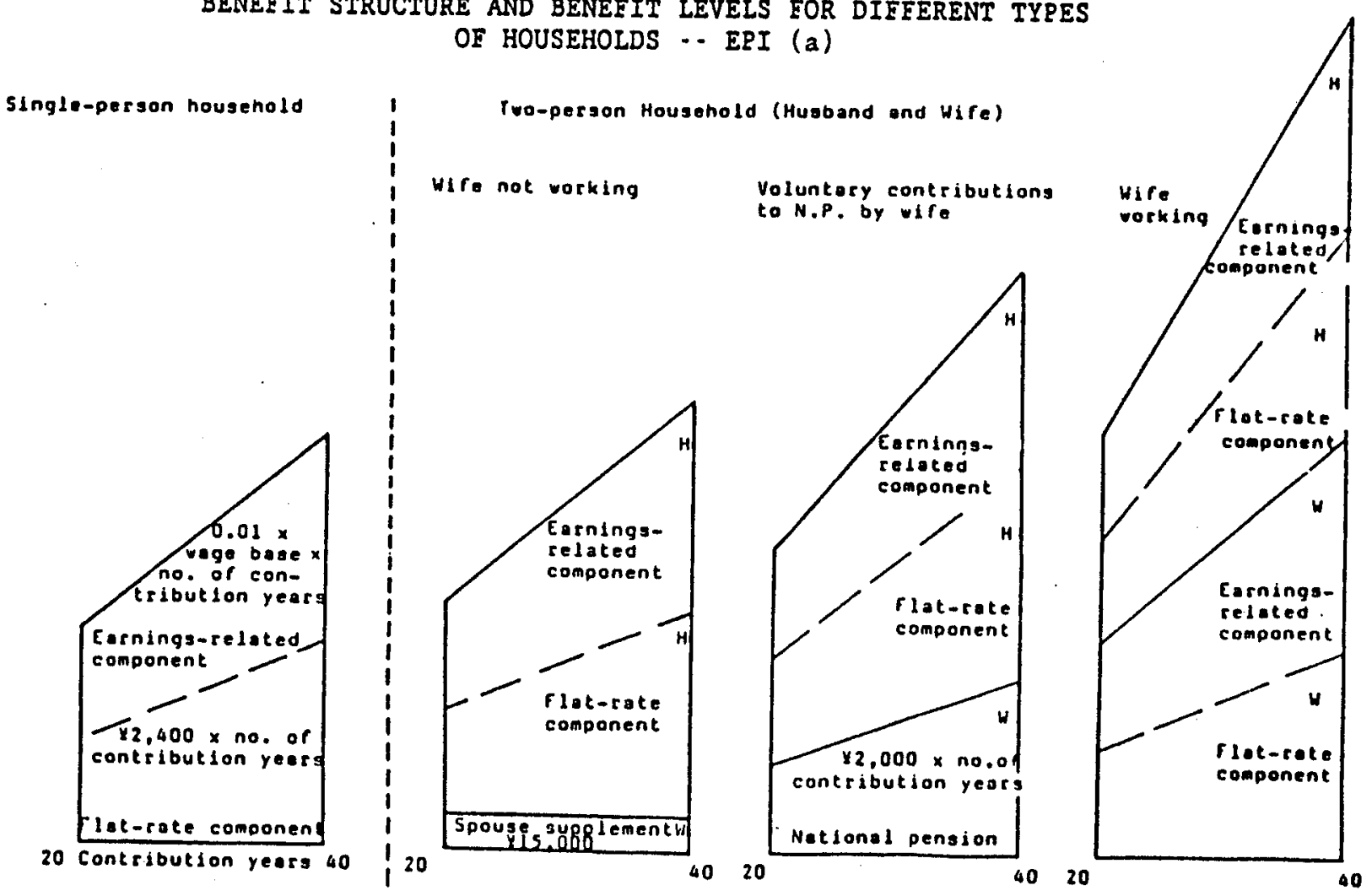

Notest a) In 1984 prices;

averago vege base of $\times 254,000 ;$ monthly amount. 
These structurally high benefit levels would result in the loss of equity between the working generation and the retired generation, would increase contributions and would thus impose a heavy burden on the generation supporting the system.

\section{Pension Security for Women}

In the EPI and the other employees' pension schemes, the standard unit for benefits is the employed husband and the unemployed housewife. This is a benefit plan for the household unit whereby coverage is through the provision of a pension to the husband. On the other hand, in the NPS the self-employed husband and wife are both insured persons and each receives an individual pension. Furthermore, it is possible for the dependent wife of an employee to receive benefits independently by becoming an optional contributor to NPS This situation creates the following problems:

\section{a) Women's rights to pensions on an individual basis}

A dependent, wife of an employee who is not optionally insured under NPS is not in a position to receive a disability pension if she herself becomes disabled. Moreover. because she has no right to an individual pension, should she later be divorced it is possible that she may not have pension protection.

b) Benefit levels for households (Chart 10)

i) Because of NPS optional coverage, there are households which are entitled to both employees' insurance (with the household as the unit) and national pension for the wife. This results in excess benefits for these households.

ii) The increased participation of women in the labour force is resulting in more women entitled to their own employees' pensior. Consequently there are an increasing number of households entitled to two employees' pensions, each based on the household as a unit.

iii) In EPI for a husband and wife household a monthly increment for the wife of $¥ 15000$ is added to the husband's benefit. This increment is only about 10 per cent of the standard pension amount. That is, the difference between a husband and wife household and single person household is a mere 10 per cent of the total benefits, so that the benefit level for the household unit can be seen to be excessive when applied to the single person household.

\section{c) Problems of voluntary participation schemes}

While the dependent wives of employees may subscribe to NPS on a voluntary basis, there is concern that because they can join and withdraw from the scheme at will it could destabilise the public pension system. 


\section{d) Pension protection for the disabled}

There is one problem in particular concerning pension protection for the disabled. While the normal disability benefit is provided if a person is disabled after having become a contributor to a pension scheme, should the disability occur before the age of 20 (unless the individual is covered by EPI) disability benefit is not supplied. Instead, a small benefit (Grade $1 ¥ 39800$, Grade $2 ¥ 26$ 500) is provided by state subsidy. This is lower than the disability benefit supplied to persons contributing to the national scheme. The occurrence of a disability requiring insurance coverage is impossible to predict within the young age cohorts, and it has been suggested that the large difference in benefit depending on whether or not the person becomes disabled before or after age 20 is unfair.

\section{REFORM OF PUBLIC PENSION SYSTEM}

\section{REORGANISATION OF THE SYSTEM WITH THE INTRODUCTION OF BASIC BENEFIT}

\section{Introduction of Basic Benefit}

The first step in the current reform of the system is its reorganisation through the introduction of basic benefits. This involves the provision of a national basic benefit scheme common to everyone in the country. In addition to the self-employed, farmers and other contributors to NPS, salaried workers and their wives will also subscribe to this scheme. Because the basic benefit is to be universal, this pension component is to be supported by the whole population.

In addition, EPI is being reformed to make available benefits corresponding to the present earnings-related component. Accordingly, the national scheme will be the basis for the public pension system and EPI which has been responsible for the first-tier component of pension benefit for salaried workers, is to take on the second-tier component. The system reorganisation is displayed in Chart 11 .

With the introduction of this basic benefit, many of the problems discussed under Section III, can be solved. First, the basic benefit is common to all the schemes. Everyone in the country will receive the same benefits subject to the same conditions. As such, the discrepancies between the schemes will be corrected and intra-generational equality will be achieved. Second, because the basic benefit system is to be supported by the whole population with no distinction between the self-employed and salaried workers, repercussions due to changes in the industrial and employment structures are eliminated and stable management over the long term is made
possible.

The introduction of the basic benefit has also led to the establishment of pension rights for women and the improvement of income protection for the disabled. These points are discussed in more detail below. 


\section{The Basic Benefit as a System of Social Insurance}

As stated above, the present public pension system is a form of social insurance. One proposed option has been the introduction of a new system whereby at a certain age - 65 for example - - the same amount of benefit is supplied to everybody and the costs for this are furnished through taxation (a universal pension scheme).

The proposal to introduce a universal pension system raises the following questions:

i) If adopted, it would involve the levying of a large new tax. Would it be possible to obtain the people's consent?

ii) Irrespective of whether or not there are contributions, if benefits were provided universally, would equity be sustained between those who have contributed to the present social insurance system, and those who have not? With the introduction of the basic benefit format following the reform of 1985 , consideration was given to a universal system. It was decided, however, to continue with the social insurance system.

\section{The Basic Benefit}

For the basic benefit, the individual is designated as the unit. In the case of the old age basic benefit, the amount is $¥ 50000$. ( $¥ 100000$ for a married couple. 1984 prices, indexed to CPI) This level, which meets basic needs in old age and which matches the actual living costs for the elderly. assumes contribution to National Insurance over 40 years. Should the individual not have paid the contributions for a certain period, a reduction proportionate with the period is made from the $¥ 50000$.

As with old-age pension for the present national scheme, the supply of the new basic old age benefits starts at the age of 65, salaried workers and the self-employed alike. At present, for salaried workers under EPI the provision of old age pension begins at age 60 . In response to the argument that it would be premature to raise the pensionable age, EPI will supply both the first-tier and second-tier benefits for those aged 60 to 64 for the time
being.

\section{Financial Resources for the Basic Benefit}

The cost of financing the basic benefit pension is borne equally by all contributors. More specifically, this involves a sharing of the burden in accordance with the total number of contributors. However, those covered by EPI (salaried worker husbands) and their dependent wives do not pay NI for these costs individually. Instead, the employees' schemes pay the required amount to the national scheme as a transfer from contributions they receive.

It should also be noted that in principle the state subsidy is concentrated on the finance required for basic benefits. 
Chart 11

SYSTEM REORGANISATION

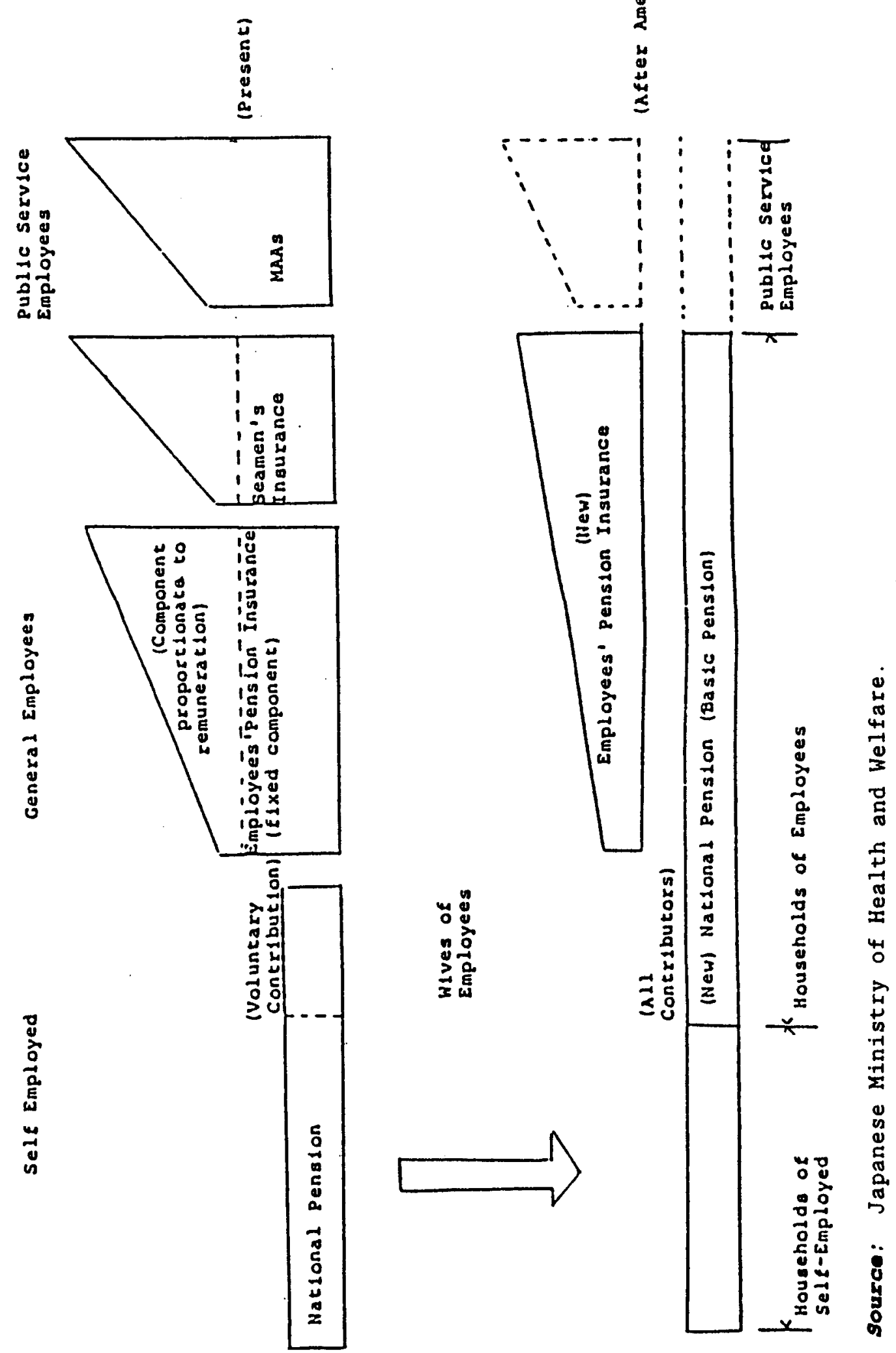


Present law

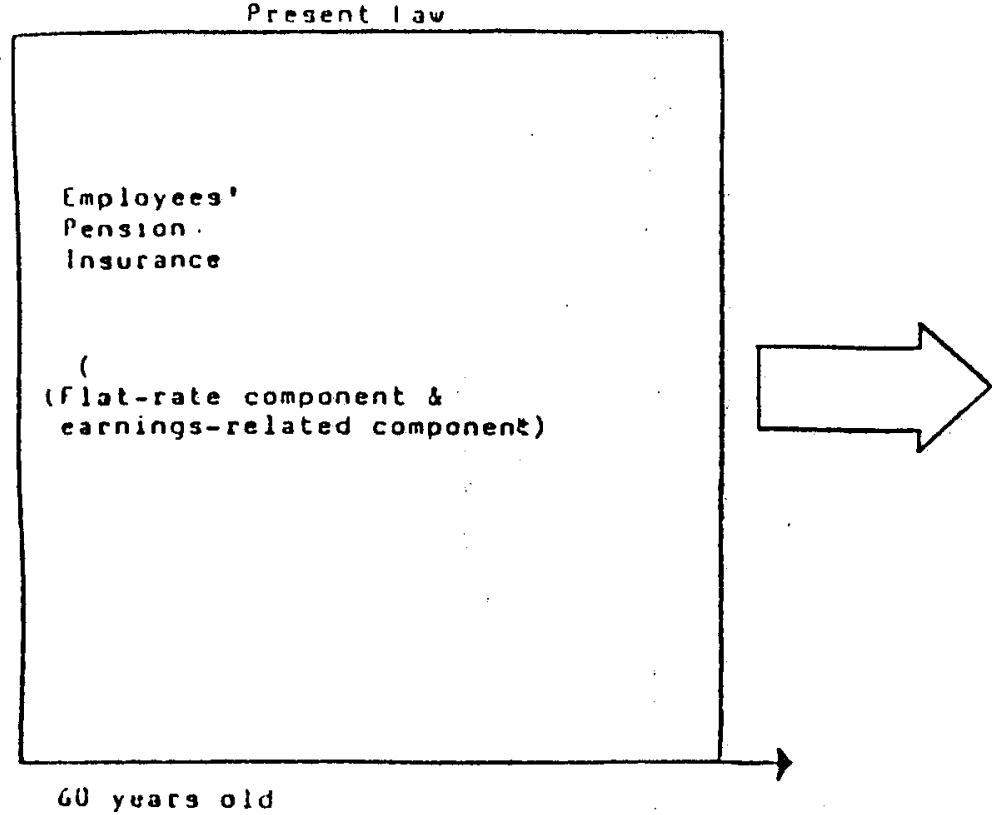

Amended'tau

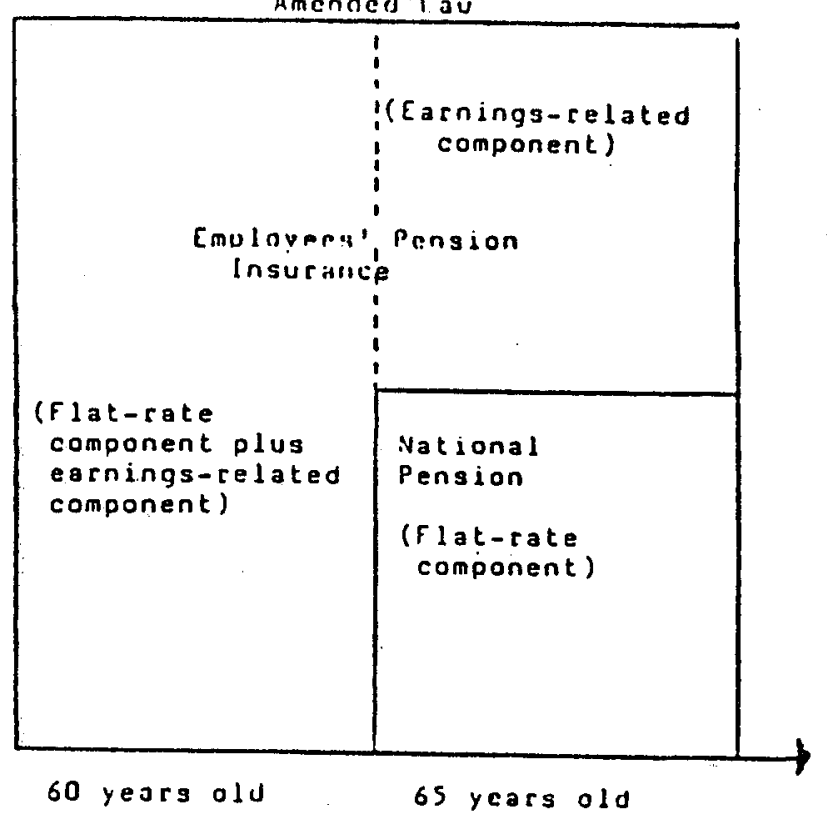

Source for both Chart 12 and 13: Japanese Ministry of Health and Welfare.

Chart 13

COMPARISON OF OLD AGE BENEFITS FOR SALARIED WORKER HOUSEHOLDS

Comparizon of Old Age Benatits tor Salarted Horker Hougeholda

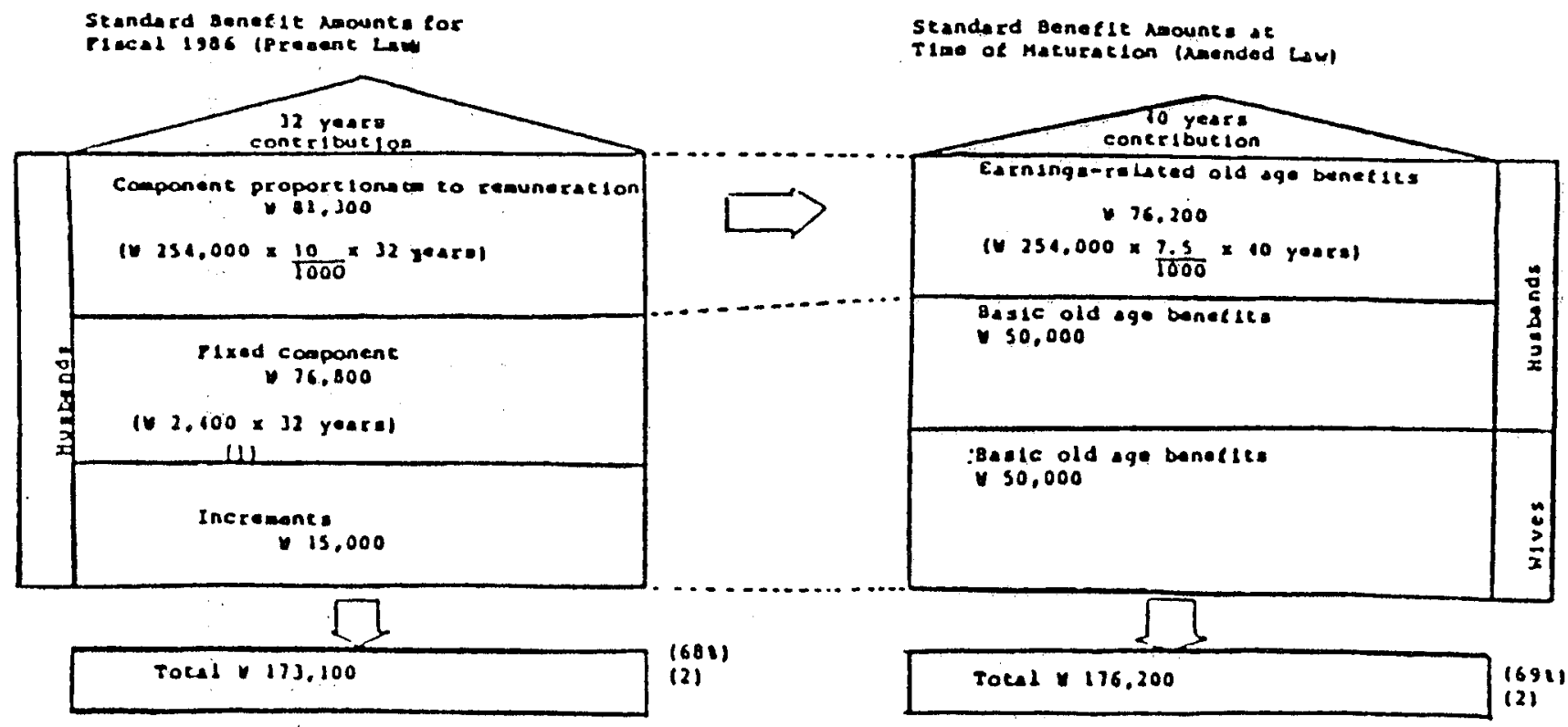

heougk Al 1984 pricen

(1) Unit price of 2,050 ac timu of 1980 amondente converted to 1984 prices

(2) Ia the ratio co the average etandard monthly wage for wale workere of 251,000 


\section{RATIONALISATION OF BENEFITS AND LIABILITIES}

\section{Rationalisation of Benefit Levels}

As pension schemes mature the average contribution period will continue to lengthen so that in time the typical period will be 40 years. Once this stage is reached an adequate level will be established for pension benefits whereby a balance is achieved between pension benefits and the net wages (after the deduction of tax and social insurance contributions) of the working population which is supporting the system. As stated in Section I, as far as EPI is concerned, if the system remains unchanged at the time of maturity. benefit levels will be 83 per cent of average wages for the actively employed. In the typical case, an actively employed person supports the expenses of a household of four, the married couple and two children. By contrast, an elderly household in receipt of pension benefits comprises two persons. There should be a balance between the benefit level for this elderly couple and the income level and liabilities of the employed person.

Following the 1985 reform, although the average number of contribution years is increasing as the system matures, the pension levels are to be gradually reduced over a 20 -year period. The objective is a benefit level for a salaried worker's household of 68 per cent of the average wage for a male (excluding bonuses). This level of benefit is to be maintained in the future.

For those already receiving pension benefits and elderly persons who are above the fixed age for retirement (those above age 60 in April 1986). consideration has been given to the fact that benefits play an important part in their plans. Their benefit levels will not be affected by the present amendment and will be maintained in the future.

\section{Rationalisation of Liability Levels}

As the pension schemes mature the benefit costs will inevitably increase. To guarantee the requisite financial resources to cope with this situation, it will be necessary to plan for increases in contributions by degrees. It is estimated that if the current benefit levels are maintained. during the peak period contribution rates would be nearly four times what they are now $(38.8$ per cent for EPI [shared equally between employers and employees], ¥19 500 for NI [1984 prices]). In the case of EPI almost 20 per cent of the salaried worker's wage would be levied as contributions and as such the balance between the salaried worker's net wage and the benefits for pension beneficiaries would be destroyed. By substantially curbing the increase in contributions through the rationalisation of benefit levels mentioned above, it is estimated that during the peak period they will be confined to 28.9 per cent (shared equally between employers and employees) for EPI and $¥ 13000$ (1984 prices) for NI (Chart 14, Chart 15).

The question arises as to whether age 60 should be maintained as the pensionable age for EPI notwithstanding the amendment of 1985 . If this age were to be raised to 65 in future, at the peak time the insurance premium rate would be still lower at 23.9 per cent. 
Chart 14

PROJECTION OF CONTRIBUTION RATE - - EPI 1986-2045

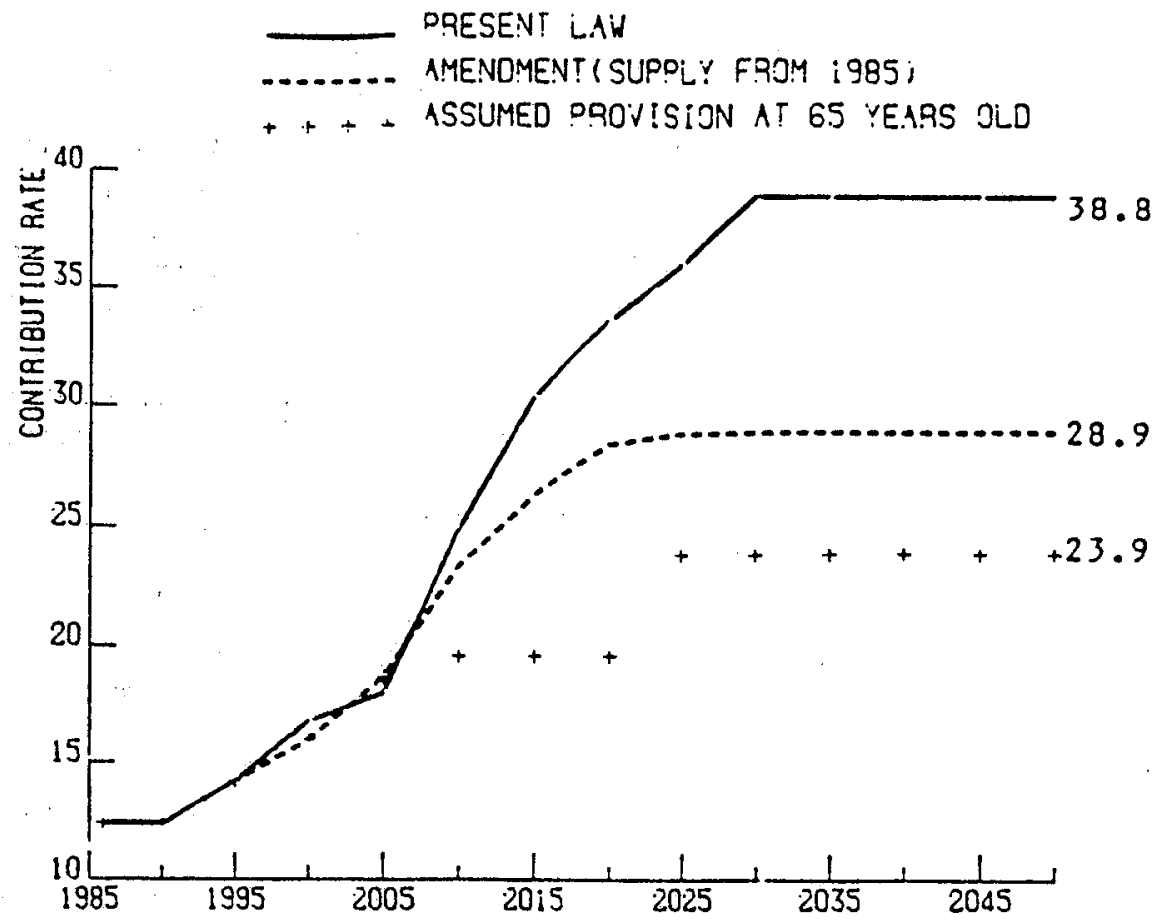

Chart 15

PROJECTION OF CONTRIBUTION AMOUNT - - N.P.

1986-2045 (in 1984 prices)

DRESENT LAW

......... AMENDMENTI SUPPLY FROM 1985;

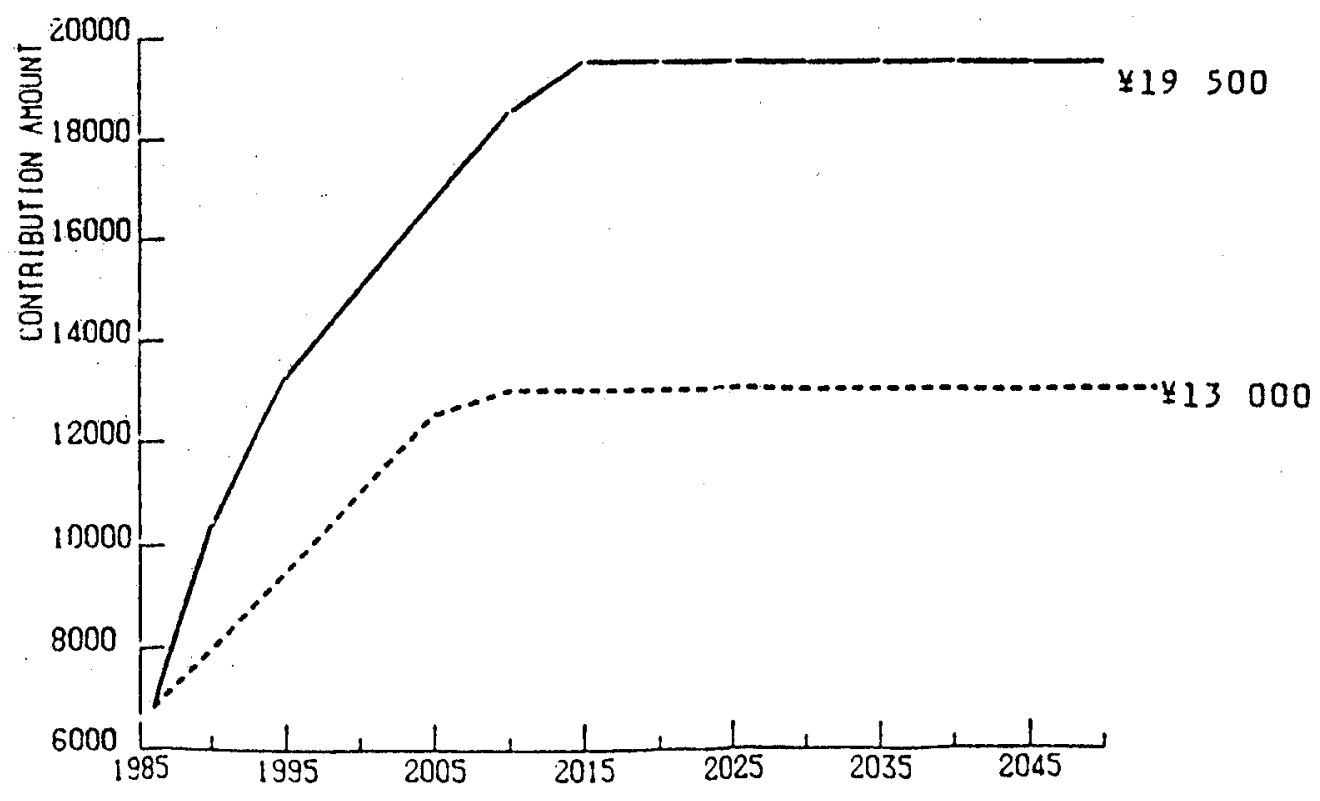

Source: Japanese Ministry of Health and Welfare. 


\section{IMPROVEMENT OF PENSION PROTECTION FOR WOMEN AND THE DISABLED}

\section{Establishment of Women's Rights to Benefits}

With the 1985 amendment the application of the national scheme has been extended to include salaried workers and their dependent wives. Each contributor, including the dependent wives of salaried employees, will be provided with basic benefits under his or her own name. Dependent wives will become compulsory participants in the national scheme. If they become disabled they will receive their own disability basic benefits, and if they are divorced they will be provided with their own old-age basic benefits once they have reached the requisite age.

However, it will not be necessary for the dependent wives of salaried workers to pay the contributions to the national scheme themselves. The employees' schemes to which their husbands belong will pay the national scheme contributions as a transfer.

\section{Rationalisation of Benefit Levels for Households}

If there is a relationship between the basic benefits brought by the amendment and previous earnings-related benefits, the previous fixed component and increments are differentiated in the basic benefits for the husband and wife respectively.

Thus:

Single person household ....... basic benefits + benefits proportionate to remuneration;

Husband and wife household ..... (husband) basic benefits + benefits (wife not working) proportionate to remuneration + (wife) basic benefits.

The benefit for a single person household has been 90 per cent of that for $a$ husband and wife household, and it will now become 70 per cent in the case of standard beneficiaries, thus more closely reflecting needs.

In households where both the husband and wife work, the levels will be adjusted so that they each receive their own basic benefit plus a benefit

\section{Improvement of Pensions for the Disabled}

Following the 1985 amendment, the discrepancies in disability benefits described in Section 1 are to be eliminated. The introduction of basic benefit will provide one scheme irrespective of occupation. Those who become disabled before age 20 are to be provided with the same disability basic benefits as those who become disabled after age 20 . Hence, the inequalities between disabled persons are to be corrected and the disabled will be supported by the country as a whole. 


\section{ISSUES FOR FUTURE EXAMINATION}

While the basic framework of the future pension system has been accomplished with the enactment of the amendment of 1985, this does not mean that all problems faced by the present system have been solved. There are many issues still requiring attention, some of which are presented briefly in the following section.

\section{Benefits and Contribution Rates for the Self-Employed and Others}

As a result of the amendment, only the first component of the two-tier benefit system (basic benefits) is available to the self-employed. There is a strong feeling that, like salaried workers, the self-employed should also receive the second component (benefits proportionate to remuneration). Should the latter be introduced, contributions would also have to be proportionate to remuneration. Because there are cases of low-income persons unable to meet the present fixed contributions, there are calls for the introduction of a system whereby contributions are proportionate to income even with a given component of fixed benefits. As far as both benefits and contributions are concerned, the introduction of elements proportionate to income is a matter to be examined.

However, the following problems arise:

i) Generally speaking "retirement" from active employment has different implications for the self-employed and salaried workers. In the case of salaried workers, there is normally a fixed age for retirement, but this is not so for the self-employed. And while the self-employed have business assets to sell, salaried workers do not. Therefore, it does not necessarily follow that the same benefit levels are required;

ii) When introducing a proportionate element for liabilities, it is difficult to assess incomes fairly for persons presently insured under the national scheme given the range of occupations self-employment covers. (If the income for the present taxation system were used, inequalities in the assessment of incomes for taxation would be carried over to pensions);

iii) If earnings-related benefits were to be established as a second component, would it be possible to enforce extra contributions upon the persons presently insured under the national scheme (many of these are in receipt of relatively low incomes)?;

iv) The introduction of insurance premiums proportionate to income into the financing scheme for fixed benefits implies liabilities in accordance with income which are not reflected in benefits. It would therefore be difficult to obtain the people's consent.

\section{Pensionable Age}

The crux of the problem as to when the provision of benefits should begin is: to what age can the actively employed make a living by working and from what age should they be regarded as elderly and be supported by pensions? Those aged 20 to 59 who have supported the society, economy and pension system 
have throughout this century comprised some 56 per cent of the total population. However, in the future this group will decrease rapidly by 2010 it is forecast that they will constitute 49.8 per cent, or less than half the total population (Chart 6).

However, if society arranges things so that people are actively employed until they are 65 years old, the proportion of the age group supporting society would remain at the same level as it is now. In order to maintain a viable society in the 21 st century, it is important to prepare the environment for the employment of the elderly and to augment the age group
supporting the society and economy.

Although the amendment of 1985 has left aside the issue of pensionable age, this problem will have to be solved in the future. Based on future employment trends of the elderly it will be necessary to study the benefit
aspect.

\section{Management of Pension Reserves}

At present, the reserves of EPI and NPS are consolidated as postal savings and other public funds and are used as capital for financial investment by the State. Given that the contribution burden will increase over the long term, pension funds will have to be managed so as to give the best possible returns in order to mitigate this burden as much as possible. In addition, to accumulate the compulsorily levied contributions, participants must endorse the way in which the funds are being managed.

With financial liberalisation, there will be changes in the circumstances concerning the application of funds. The policy is currently under discussion the government, though some think that the postal savings and
other public funds comprising the pension reserves should still be utilised jointly. There is need for a full discussion on this point.

\section{The Taxation of Pensions}

In Japan, contributions for public pensions are currently deducted from the taxable income of the individual. Disability and survivors' benefits in the public scheme are not taxed. While old age benefits are subject to taxation, they receive more favourable consideration than the incomes of the actively employed. An active salaried worker in a household comprised of a married couple and no children is taxed on income in excess of $¥ 1230000$, while a pension beneficiary over age 65 is taxed on income only in excess of Y2 300000 is untaxed. This is because pension income is deemed to be wages. In addition to receiving a wage income deduction, pension beneficiaries over 65 also qualify for the special old-age pension deduction. Some argue that pension beneficiaries are treated too favourably and that there is a need for this system to be reassessed.

However, the present taxation system for pension beneficiaries has been established as part of the welfare policy for the elderly. This system has become a fixture among pension beneficiaries, and in that any review would significantly affect the situation, there is a strong view that the present system should be maintained or even improved. It will be necessary to study
this issue in detail. 


\section{THE PRESENT SITUATION OF OCCUPATIONAL PENSIONS}

\section{OCCUPATIONAL PENSION PROVISIONS}

The full-scale introduction of Japan's occupational pensions was inaugurated after the establishment of the tax-qualified pension scheme in 1962 and the employees' pension fund scheme in 1966. Occupational pensions are provided either in place of the fixed retirement lump-sum grant traditional to Japan or in combination with the latter. As of the end of March 1984, those contributing to the employees pension fund and tax-qualified pension schemes numbered 13 million, 6 which corresponds to 50.9 per cent of the insured persons covered by EPI.

\section{Employees' Pension Fund System}

The employees' pension fund, as prescribed in the Employees' Pension Insurance Act, is a scheme which substitutes the earnings-related component of old-age pension of EPI and also provides extra benefits. While it is up to the individual enterprise whether or not to establish an employees' pension fund, the authorisation of the Minister for Health and Welfare is necessary for its establishment. The legislation of the employees' pension fund is based on the Employees' Pension Insurance Law. It is an authorised corporation, comprising representatives of the management and the insured persons.

Employees' pension funds thus established can be of three types: the "single establishment" set up by one enterprise, the "combined establishment" jointly instituted by a parent company and its subsidiaries, and the "collective establishment" jointly founded by a number of enterprises in the same type of business. Legally, these funds should have at least 1000 members, although in the case of the collective establishments, over 5000 members are required.

With the establishment of an employees' pension fund, contributor are exempted from paying contributions for the earnings-related component of EPI to the State (at present corresponding to 32/1000). With the contributions thus exempted and with extra instalments from its management and employees, the fund enters into a pension provision agreement with a trust bank or life insurance company and provides retirement pensions to its members.

In principle, the benefits provided by employees' pension funds are life-long pensions and the amount must be in excess of the pension component proportionate to income supplied through EPI. Additionally, the extra benefits provided by the enterprise must, on a cost basis, be more than 30 per cent of the component it supplies on behalf of the state.

\section{Tax-Qualified Pension}

The tax-qualified pension scheme is determined under the Tax Law and its establishment is subject to certain conditions. There are twelve conditions in all, and include concluding a trust or similar agreement and the 
laying aside of external reserves, instalments and benefits to be calculated on the basis which is appropriate in the actuarial view, and the amounts which are reserved for retirement pension benefits not being returned to the management. For retirement pension agreements approved by the director of the National Tax Administration Agency, favourable measures can be authorised with regard to taxation.

There are three types of tax-qualified pension agreement: a trust agreement with a trust company, a life insurance agreement with a life assurance company, or a mutual aid agreement with the National Agricultural Co-operatives Association. In the case of the latter two types of agreement 20 or more members are required, while for a trust agreement the membership must be 100 or more persons.

Tax-qualified benefits need not be for life, and pension plans for a definite term of five years or more are acceptable. It is also possible for retirees to opt for a lump-sum retirement grant, which in fact most choose.

\section{Present State of Affairs of Occupational Pensions}

The numbers of occupational pension schemes, contributors and beneficiaries are shown in Table 7 :

Table 7

OCCUPATIONAL PENSION FUNDS

As of the end of March 1984

Employees' Pension
Fund

$\begin{array}{lcc}\text { Number of funds or contracts } & 1043 \text { funds } & 65346 \text { contracts } \\ \text { Number of contributors } & 6563000 & 6868000 \\ \text { Number of beneficiaries } & 825000 & 67000\end{array}$

According to the results for fiscal 1984, the average benefit amount provided by the employees' pension funds, which included benefits for persons who had only been contributing over the short term, was ¥113000 (annual amount). It is predicted that with the future extension of the average contribution period, the benefits will also rise.

With a view to preserving the rights of the contributors to receive benefits, the management of both employees' pension funds and tax-qualified pension finances has been based on the full-funding method. As of the end of March 1984 these pension assets amounted to $¥ 8800000$ for the employees. pension funds and $¥ 5300000$ for eligible retirement pension for a combined total of $¥ 14000000$ (Table 8). 
Table 8

\section{RESERVE ESTIMATES}

Employees' Pension
Fund
$¥ 1000000$ million

Employees' Pension

$¥ 1000000$ million
(For each fiscal year)

Tax Qualified

Pension

$¥ 1000000$ million
1980

1981

1982

1983
4.9
6.0
3.0
7.3
3.7
8.8
4.5
5. 3

\section{PROBLEMS OF OCCUPATIONAL PENSIONS}

The public has high and increasing expectations that occupational pension schemes, together with the public pension system, are an important means of providing income security in old age. Given this situation, the future problems facing occupational pensions can be summarised as follows:

- First, the fundamental role of occupational pensions as a provider of income security in old age, its relationship to the public pension system in view of the rapidly ageing population structure, changes in the social and economic conditions, and the upheaval implied in the reform of the public pension system as a whole, all must be clarified.

- Second, while occupational pensions, comprising the employees' pension funds and tax-qualified pensions, now cover about half of those insured under EPI, they should be promoted further so that as many employees as possible are covered. To this end, and to ensure conditions whereby it is easy for sma11- and medium-size enterprises to establish employees' pension funds and to offer attractive benefit packages, it is not only necessary to make the benefit plans flexible, but also to rationalise their administration and to promote them as much as possible.

- Third, in that the occupational pension assets constitute vital resources for future benefits of the contributors, how they are managed will have enormous repercussions on finances. It is therefore of utmost importance for the occupational pension schemes that every effort be made to efficient management. 


\section{NOTES}

1. EPI is applicable to persons employed at places of work which normally employ five or more persons. For other persons, NI is applicable. With the amendment of 1985, EPI is applicable to all those employed in the offices of corporations irrespective of the number of employees.

2. Seamen's Insurance to cover seafarers as a system for a single occupation was commenced in 1940 .

3. When a person becomes a dependent spouse he or she does not compulsorily participate in any scheme. However, optional participation in NPS is possible.

4. Pension benefits for EPI are comprised of an earnings-related component, a flat-rate component and increments.

5. Here the average wage for the actively employed excludes bonuses.

6. Because some enterprises operate both schemes, there is some overlapping as far as the numbers of contributors are concerned. 
